\title{
Development of an in vitro pancreatic tissue model to study regulation of islet neogenesis associated protein expression
}

\author{
Maria Petropavlovskaia ${ }^{1}$, Julia Makhlin ${ }^{1}$, John Sampalis ${ }^{1,2}$ and Lawrence Rosenberg ${ }^{1}$ \\ Departments of ${ }^{1}$ Surgery, ${ }^{2}$ Clinical Epidemiology, Research Institute of the McGill University Health Center, McGill University, 1650 Cedar Avenue, Montreal, \\ Quebec, Canada H3G1A4 \\ (Requests for offprints should be addressed to M Petropavlovskaia; Email: maria.petropavlovskaia@mail.mcgill.ca)
}

\begin{abstract}
Restoration of a functional $\beta$-cell mass in a patient with diabetes may hold the key for curing the disease. In recent years, there has been increasing interest in the development of new strategies to induce $\beta$-cell regeneration and new islet formation in situ and a role for Reg proteins has been suggested. One such protein, islet neogenesis associated protein (INGAP), is a member of the Reg3 family of proteins and has been shown to induce islet neogenesis. Elucidation of the mechanisms and factors involved in the regulation of expression of INGAP and related proteins is, therefore, of great importance. Here, we report the establishment of the first in vitro tissue model of INGAP expression that consists of epithelial cystic structures derived from hamster pancreatic acinar tissue cultured in collagen matrix. The objective of this study was to characterize INGAP expression in this model and to investigate the role
\end{abstract}

of pro-inflammatory cytokines and growth factors. Using quantitative reverse transcriptase PCR, we show that INGAP expression correlates with cyst formation and size suggesting the involvement of intra-luminal pressure associated with cyst growth. We also demonstrate for the first time that INGAP gene expression was significantly induced by treatment with interleukin (IL)- 6 and further enhanced by a combination of IL-6 with dexamethazone and nicotinamide. Additionally, our data suggest that the effect of IL-6 on INGAP expression is mediated via the JAK/STAT3 signaling pathway. In summary, the in vitro model of INGAP expression described here represents an important step in the development of strategies for the use of INGAP and related proteins as islet neogenic agents in the pharmacotherapy of both type- 1 and type- 2 diabetes.

Journal of Endocrinology (2006) 191, 65-81

\section{Introduction}

Diabetes mellitus is a debilitating metabolic disease that is caused by almost complete (type-1) or partial (type-2) loss of pancreatic $\beta$-cells. Therefore, restoration of a functional $\beta$-cell mass in a patient with diabetes is an important goal of diabetes research. In recent years, there has been increasing interest in the development of new strategies to induce $\beta$-cell regeneration and new islet formation in situ (Baggio \& Drucker 2006, Lipsett et al. 2006, Rood et al. 2006). Search for growth factors involved in islet regeneration has led to the discovery of the Reg genes, which constitute a multigene family grouped into several subclasses, type- $1,-2,-3$, and -4 (Okamoto 1999, Zhang et al. 2003). Reg1 is believed to be a growth factor for $\beta$-cells and has been found in rat, mouse, hamster, and human pancreas (Okamoto 1999, Takasawa et al. 2006), whereas Reg2 has so far been found only in mice (Okamoto 1999). The functions of Reg3 proteins identified in rat, mouse, hamster, and humans and of a recently isolated human Reg4 protein, have not been well defined. These proteins expressed in various parts of the digestive system, have been associated with acute pancreatitis, inflammatory bowel disease, and neoplastic transformation and are believed to serve as mitogens and anti-apoptotic factors in cells other than pancreatic $\beta$-cells (Okamoto 1999, Honda et al. 2002, Ogawa et al. 2003, Oue et al. 2005).

Islet neogenesis associated protein (INGAP) is a member of the Reg3 family of pancreatic proteins with a specific ability to induce islet neogenesis (Rosenberg et al. 1996, 2004). INGAP was originally identified in a crude pancreatic tissue extract that was prepared from the partially obstructed hamster pancreas (Rosenberg et al. 1988). INGAP is characterized as a 175 -amino acid secreted protein that relates to the C-type lectins and that appears to be restricted to the pancreas and duodenum (Rafaeloff et al. 1997, Rosenberg 1998, Flores et al. 2003). A bio-active portion of INGAP, INGAP $^{104-118}$ peptide, has been demonstrated to be effective in inducing new islet formation and reversing streptozotocin (STZ)-induced diabetes in hamsters and mice (Rosenberg et al. 1996, 2004). These compelling results of animal studies obtained with synthetic INGAP peptide were followed by clinical trials to investigate its efficacy and safety in humans. As a result, INGAP has been found to have a signal effect with a fall in daily average blood glucose levels, confirmed by A1c 
reduction at 90 days in patients with the type- 2 diabetes and with a significant increase in C-peptide secretion in patients with type-1 diabetes (Ratner et al. 2005a,b). Longer term exposure is needed to see definitive evidence of $\beta$-cell neogenesis (Ratner et al. 2005a,b, Uwaifo \& Ratner 2005).

Although a human counterpart of INGAP has not yet been identified, stimulation of the production of its homologue in the pancreas and, as a consequence, the induction of islet neogenesis in situ, would signify a novel therapeutic approach to the treatment of diabetes. Accordingly, investigation of the mechanisms and factors involved in the regulation of expression of INGAP and related proteins is of great importance.

At present, very little is known about how INGAP expression is regulated. In addition to the original duct obstruction experiments, a number of studies have demonstrated that INGAP expression is also induced in diabetic hamsters (Takatori et al. 2003) and by sucrose administration to normal hamsters (Del Zotto et al. 2000, 2004, Gagliardino et al. 2003). These studies indicate that INGAP, like other members of the Reg family, is induced in response to pancreatic stress (Dusetti et al. 1995, 1996, Akiyama et al. 2001). However, contrary to Reg and PAP, the regulation of INGAP expression does not seem to depend on an inflammatory response (Rosenberg 1998). Circumvention of an undesirable inflammatory reaction makes INGAP an attractive target for inducing islet neogenesis in situ via upregulation of endogenous INGAP expression.

As an important step forward, the genomic sequence of INGAP has recently been identified (Taylor-Fishwick et al. 2003). The coding region of INGAP consists of six exons spanning approximately $3 \mathrm{~kb}$ of the genomic sequence, analogous to the Reg family of genes. Sequence analysis identified a $3-\mathrm{kb} 5^{\prime}$-region containing a core promoter that is rich in transcription factor-binding sites. As reported, the distribution of transcription factor sites on the INGAP promoter is distinct from the promoter of mouse Reg $3 \delta$, the closest relative of INGAP, implying that the regulation of INGAP expression may involve different mechanisms than those ascribed to other members of the Reg family of genes (Taylor-Fishwick et al. 2003).

The scarcity of information on the regulation of INGAP expression has been due in part to the lack of a cell or tissue culture model of INGAP expression in vitro. In this paper, we report the establishment of a model to study regulation of INGAP expression using primary hamster pancreatic tissue that consists of duct-like epithelial cystic structures formed as a result of acinar-to-ductal transdifferentiation during long-term culture in a collagen matrix. Using this model, we tested a number of pro-inflammatory cytokines, growth factors, and other agents, purportedly involved in pancreatic development, function, and regeneration alone, or in combination, on INGAP expression. Our results indicate that INGAP expression is influenced by an increase in intraluminal pressure inside the growing cystic structures and that it is also increased by interleukin (IL)-6 administered alone or in combination with dexamethazone (Dx) and nicotinamide (NIC). Furthermore, our data suggest that this effect of IL-6 on INGAP expression might be mediated via the JAK/STAT3 signaling pathway.

\section{Materials and Methods}

\section{Animals and pancreas digestion}

Three normal male Syrian golden hamsters (3 weeks old, $50 \mathrm{~g}$ ) were obtained from the Charles River Laboratories, Inc. (St Constant, Que., Canada) and killed by $\mathrm{CO}_{2}$ inhalation, in accordance with the Canadian Council on Animal Care guidelines. Pancreatic digestion and isolation of pancreatic acinar fragments were carried out as described previously (Yuan et al. 1997) with minor modifications. Briefly, excised pancreata were shredded using scissors and placed into $5 \mathrm{ml}$ digestive medium, containing $1 \mathrm{mg} / \mathrm{ml}$ Collagenase XI (Sigma-Aldrich) in Hanks' balanced salt solution (HBSS) (MediaTech, Herndon, VA, USA). The digestion process was carried out in a $37^{\circ} \mathrm{C}$ water bath for $30 \mathrm{~min}$ and was halted by the addition of $5 \mathrm{ml}$ ice-cold HBSS. Following dispersion by vortex for $10 \mathrm{~s}$, tissue was centrifuged at 900 r.p.m. for $2 \mathrm{~min}$ and the supernatant was discarded. The tissue pellet was washed three times in cold HBSS, resuspended in the culture medium and plated into $10 \mathrm{~cm}$ non-tissue culture-treated plates. Islets, acinar clusters, and duct fragments, identified by their morphology, were handpicked under an inverted microscope and processed for RNA extraction. Purity of the handpicked islets was verified by dithizone staining.

\section{Tissue culture}

After the removal of islets and ducts, the remaining tissue containing almost exclusively acinar fragments was embedded into collagen type-1(rat-tail) as described previously (Yuan et al. 1997) and cultured in Dulbecco's modified Eagle's medium/F12 medium (Invitrogen) supplemented with 10\% fetal bovine serum (FBS; Montreal Biotech, Montreal, Que., Canada), Dx (1 $\mu \mathrm{M}$, Sigma), epidermal growth factor (EGF) (10 ng/ml, Sigma), human insulin (Humulin, $24 \mathrm{mU} / \mathrm{ml}$, Lilly), forskolin $(2 \mu \mathrm{M}$, Sigma), penicillin $(100 \mathrm{U} / \mathrm{ml})$, streptomycin $(100 \mu \mathrm{g} / \mathrm{ml})$, and fungizone $(2.5 \mu \mathrm{g} / \mathrm{ml}$; Invitrogen). Cultures were incubated at $37^{\circ} \mathrm{C}, 5 \% \mathrm{CO}_{2}$ with the culture medium changed every other day. These conditions have been shown to favor formation of cystic structures in a long-term culture of hamster acinar fragments (Yuan et al. 1997).

The formed cystic structures were passaged bi-weekly or weekly, depending on the cell density. First, collagen was digested with $0.25 \mathrm{mg} / \mathrm{ml}$ collagenase (type-XI, Sigma) in HBSS at $37^{\circ} \mathrm{C}$ for $30 \mathrm{~min}$. Cysts were harvested in a $50 \mathrm{ml}$ tube, washed three times with HBSS and then digested with trypsin/EDTA (Invitrogen) at $37^{\circ} \mathrm{C}$ for $2 \mathrm{~min}$, followed by gentle pipetting to fragment the cysts into clusters containing 
several cells. Fragmented tissue was washed with $10 \mathrm{ml}$ culture medium, centrifuged for $4 \mathrm{~min}$ at 900 r.p.m., split 1:5 or 1:10 and re-embedded into collagen.

For some experiments, cysts were separated by size using stainless steel meshes with pore size 46 and $94 \mu \mathrm{m}$ (Bellco) to enrich for big and small cysts respectively.

\section{Treatment of hamster cysts}

All experiments were carried out on 5- to 7-day-old cultures containing well-formed cystic structures. On the day of treatment, the culture medium was removed and replaced with culture medium, that contained 1\% FBS but excluded Dx and forskolin. Cells were treated with the indicated amounts of the following factors: $10 \mathrm{mM} \mathrm{NIC} \mathrm{(Sigma),}$ 100 nM Dx (Sigma), human IL-6, 20 ng/ml HGF, $200 \mathrm{U} / \mathrm{ml}$ IL-1 $\beta, 100 \mathrm{ng} / \mathrm{ml}$ tumour necrosis factor (TNF) $\alpha, 100 \mathrm{ng} / \mathrm{ml}$ interferon (IFN) $\gamma, 20 \mathrm{ng} / \mathrm{ml}$ betacellulin (BTC), and $20 \mathrm{ng} / \mathrm{ml}$ keratinocyte growth factor (KGF) (R\&D Systems). Cysts were harvested $24 \mathrm{~h}$ later as described earlier and lysed in the RLT buffer (Qiagen) for RNA extraction.

\section{$R N A$ extraction and $q R T-P C R$}

Total RNA from untreated and treated cystic structures was extracted using RNeasy Mini kit (Qiagen) and RNA concentration was measured spectrophotometrically at $260 \mathrm{~nm}$. Total RNAs $(1 \mu \mathrm{g})$ were converted into cDNA by incubating with oligo-dT primer (Invitrogen) and OmniScript reverse transcriptase (Qiagen) at $37^{\circ} \mathrm{C}$ for $1 \mathrm{~h}$. Handpicked samples containing small amounts of RNA were subjected to RNA extraction with RNeasy Micro kit followed by reverse transcription with SensiScript (both from Qiagen). Non-quantitative PCR was performed with Hotstart DNA polymerase kit (Qiagen), for 35 cycles. PCR conditions were: $95^{\circ} \mathrm{C}, 15 \mathrm{~min} ; 35 \times\left(94^{\circ} \mathrm{C}, 30 \mathrm{~s} ; 55^{\circ} \mathrm{C}\right.$, $30 \mathrm{~s}$, and $\left.72^{\circ} \mathrm{C}, 1 \mathrm{~min}\right)$. Real-time PCR consisting of 40 cycles of denaturing at $94^{\circ} \mathrm{C}, 30 \mathrm{~s}$, annealing at 55 or $58^{\circ} \mathrm{C}$, $30 \mathrm{~s}$ and extension at $72{ }^{\circ} \mathrm{C}, 30 \mathrm{~s}$ was carried out in $20 \mu \mathrm{l}$ volume containing $1 \mu \mathrm{l}$ cDNA, QuantiTect SYBR Green
PCR Master mix (Qiagen), and $0 \cdot 25 \mu \mathrm{M}$ custom made primers (Invitrogen). All reactions were performed in duplicates, on samples from at least three experiments. Real-time PCR data were collected using the DNA Engine Opticon2 real-time cycler (MJResearch, Waltham, MA, USA). Relative quantities of the transcripts were calculated by normalizing to the quantity of $\beta$-actin transcript, using the formula $2^{-\Delta \Delta C_{\mathrm{t}}}$, and thus resulting in estimation of fold change in expression (Livak \& Schmittgen 2001). Choice of $\beta$-actin, as an internal control gene, was based on the observation that $C_{\mathrm{t}}$ for $\beta$-actin did not vary under different experimental conditions, if equal amounts of RNA were used. PCR efficiencies for different pairs of primers were verified by a standard curve method on serially diluted templates and were found to be approximately equal and close to 1 in a range of $2 \mu \mathrm{g}-2 \mathrm{ng}$ starting amounts of RNA.

Primer design Primers used for amplification of INGAP were derived from the published sequence of INGAP cDNA (Rafaeloff et al. 1997) (Table 1). Primers for hamster STAT1 and -2 were derived from the hamster sequences available from the GeneBank. Due to the lack of published hamster sequences, primers for the other genes of interest were designed to match the regions homologous between mouse and rat sequences, assuming that these regions are conserved between species. Primer sequences and the length of the amplicons are summarized in Table 1. PCR efficiency of mouse primers for IL-6R $\alpha$ was low with hamster cDNA, as compared with mouse cDNA (three pairs of primers were used). To engineer more specific primers, PCR products generated using mouse primers were sequenced, their identity as IL-6R $\alpha$ was confirmed based on $85 \%$ homology with the mouse sequence using BLAST (NCBI, NIH), and then hamster-specific primers were designed based on that sequence. All PCR products were first analyzed on $1 \%$ agarose gel to verify the size and the absence of multiple bands and were then sequenced at the McGill University Genome Centre (Montreal) using the same primers. In general, PCR products had $85-90 \%$ homology with the appropriate mouse sequences.

Table 1 Primers used for quantitative real-time RT-PCR

\begin{tabular}{|c|c|c|c|}
\hline & Forward primer & Reverse primer & Product size $(b p)$ \\
\hline \multicolumn{4}{|l|}{ Gene } \\
\hline INGAP & GСТTCССАТGАСССТСТGTA & CCGTCAAACTGTTCTTCACAAG & 286 \\
\hline$\beta$-Actin & ССТTССТGGGTATGGAATCC & CACCGATCCACACAGAGTAC & 233 \\
\hline$\alpha$-Amylase & GCAGAGGAAACAGAGGATTCATTG & GCTTTGCСАTСАСТGССАACAT & 165 \\
\hline STAT1 & GAACAGCTGCTGCTCСАСАA & GTCTTCGCTTCСАСТССАСТ & 144 \\
\hline STAT2 & AGGAACGCCGACTGCTGAA & GCACGGAGTAGATGACCACTTTA & 131 \\
\hline STAT3 & САGTTCTCGTCСАССАССАA & TCCСGСТССТTGСТGATGAA & 250 \\
\hline JAK1 & ATCGCСТCTGATGTCTGGTCTTT & ATCAGGACAGTTGGGTGGAC & 188 \\
\hline JAK2 & CAGCСТGTTTACTCСАGАTTATG & СТСТСТTСАAАCTGTGTAGGG & 122 \\
\hline GP130 & GGACCAAAGATGCСТСААСTTG & СТСАСТССАGTСАСТССАGTA & 160 \\
\hline$I L-6 R \alpha$ & TTGCTGGTGGATGTTCCTCC & TGGTAAACTCTGTCGСССТC & 244 \\
\hline CK19 & ССTGAGTGAGATGAGAAGTCA & TCCAGGGCAGCTTTCATGCT & 218 \\
\hline
\end{tabular}




\section{Western blot analysis}

Cystic structures were collected by digestion of collagen with collagenase XI, as described above, washed three times with HBSS and solubilized in lysis buffer $(50 \mathrm{mM}$ HEPES, $150 \mathrm{mM} \mathrm{NaCl}, 100 \mathrm{mM} \mathrm{NaF}, 10 \mathrm{mM} \mathrm{Na} \mathrm{P}_{2} \mathrm{O}_{7}, 1 \% \mathrm{NP}-$ $40,10 \%$ glycerol, and $\left.1 \mathrm{mM} \mathrm{NaVO}_{4}\right)$, activated by $\mathrm{H}_{2} \mathrm{O}_{2}$ for $10 \mathrm{~min}$ thus forming pervanadate (Ruff et al. 1997), and complete protease inhibitor cocktail tablet (Boehringer Mannheim, Indianapolis, IN, USA). The amount of protein was measured with a Bio-Rad Protein Assay Dye Reagent (Bio-Rad). An equal amount of protein $(100 \mu \mathrm{g})$ was resolved by $12 \cdot 5 \%$ SDS-PAGE, followed by transfer onto nitrocellulose membrane (Bio-Rad) at $250 \mathrm{~mA}$ for $90 \mathrm{~min}$ and analyzed with different antibodies. Anti-p44/42 MAPK and antiphospho-p44/42 MAPK (Thr202/Tyr204), anti p38 MAPK and anti-phospho-p38 MAPK (Thr180/Tyr182), and rabbit polyclonal antibodies were purchased from Cell Signaling, Inc. (Beverly, MA, USA). Anti-GAPDH, polyclonal, was from Abcam (Cambridge, MA, USA). Following primary antibody incubation, blots were washed and then incubated in a secondary, anti-mouse or anti-rabbit HRP-conjugated antibody (Amersham Life Sciences), washed and developed using the ECL system (Amersham). To analyze the expression of several proteins on the same blot, membranes were stripped by incubating at $65^{\circ} \mathrm{C}$ for $30 \mathrm{~min}$ in stripping buffer $(100 \mu \mathrm{M}$ $\beta$-mercaptoethanol, $2 \%(\mathrm{w} / \mathrm{v}) \mathrm{SDS}$, and $62.5 \mathrm{mM}$ Tris- $\mathrm{HCl}$ $(\mathrm{pH} 6 \cdot 7))$ and re-probed with another primary antibody.

\section{Statistical analysis}

The estimated differences in gene expression between the experimental and the control groups are expressed as fold change (over control) and are mean \pm s.E.M. The statistical significance of the observed differences was determined either by two-tailed Student's $t$-test or by one-way ANOVA followed by Tukey's least significant difference (LSD) adjustment for multiple comparisons. The linear dose-response relationship between IL-6 and levels of INGAP mRNA was tested with simple linear regression analysis.

\section{Results}

INGAP expression in isolated pancreatic fragments and acinar-derived cysts

Expression of INGAP in freshly isolated acinar tissue, ducts, and islets obtained as described in Materials and Methods, was assessed by RT-PCR. Due to the lack of an INGAP-specific antibody that would not cross-react with other Reg proteins, we limited this study to the assessment of INGAP mRNA. Thirty-five cycles of PCR yielded detectable products from the acinar tissue, islets, and ducts (Fig. 1). Relative expression of INGAP in the acinar tissue and islets was further examined by qRT-PCR and analyzed by the $2^{-\Delta \Delta C_{\mathrm{t}}}$ method, using actin
1

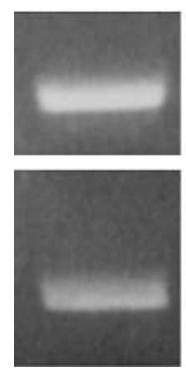

2

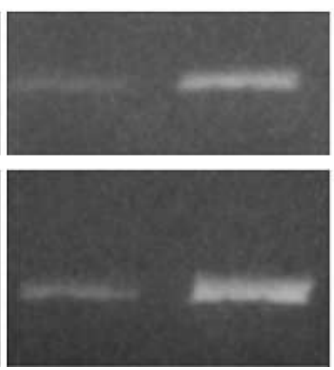

INGAP

Figure 1 Expression of INGAP in isolated acinar tissue, ducts, and islets. Total RNA from handpicked fragments of acinar tissue, islets, and ducts was isolated using RNEasy Micro kit (Qiagen) and reverse-transcribed with SensiScript (Qiagen). PCR was performed with Hotstart DNA polymerase kit (Qiagen), for 35 cycles as described in Materials and Methods. PCR products were resolved on $1 \%$ agarose gel. Lane 1 , acinar tissue; lane 2, ducts; lane 3, islets.

as a reference gene, as described in Materials and Methods. Our results show that islets express INGAP mRNA at $64 \cdot 4 \pm$ $8 \cdot 5 \%$ of the acinar tissue level. To account for a possibility of contamination of islets with acinar tissue, we performed qRTPCR for $\boldsymbol{\alpha}$-amylase in all samples and found that the islet RNA preparation contained $\alpha$-amylase mRNA at only $0.02 \%$ of the acinar tissue level. This confirms that most of the INGAP mRNA in the islet preparation has an islet origin. Contamination of islets with ducts was highly unlikely, because ductal fragments were very rarely seen. Due to the scarce amount of RNA obtained from the handpicked ducts, no accurate quantitative assessment of INGAP expression was possible, although presence of a correct PCR product was confirmed both by the melting curve analysis and on agarose gel. Taken together, our data indicate that INGAP is expressed in all parts of normal hamster pancreas and confirm the notion that acinar tissue is a predominant source of INGAP expression (Rafaeloff et al. 1997, Flores et al. 2003).

Acinar tissue embedded in type-1 collagen and cultured in the presence of EGF and forskolin for approximately 2 weeks, transformed into duct-like epithelial cystic structures of various sizes and shapes (Fig. 2A and B). Phenotypic changes associated with this process characterized in detail in the earlier report from our laboratory, correlate with a decline in amylase immunopositivity and a significant increase in $\left[{ }^{3} \mathrm{H}\right]$ thymidine incorporation (Yuan et al. 1997). In this study, we show by qRT-PCR that more than $99 \%$ amylase mRNA was lost within the first 12 days in culture, whereas expression of the ductal marker CK19 increased approximately tenfold (Fig. 2D). As shown, this trend continued throughout the following weeks resulting in a complete acinar-to-ductal conversion after 2 months in culture.

We have been able to maintain the proliferative capacity of the cyst epithelial cells for extended periods in culture. Thus, cells were continuously propagated for 7 months before creating frozen stocks. Cultures were periodically re-constituted when needed by thawing cells that were 
A

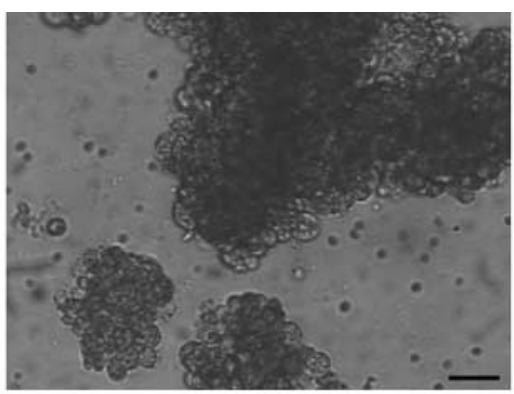

B

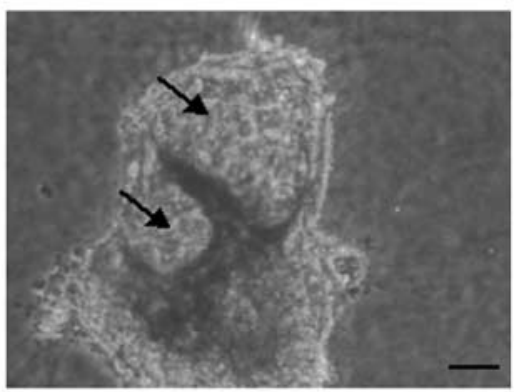

C

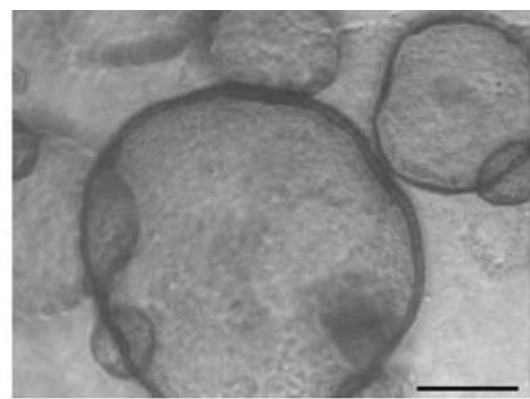

D

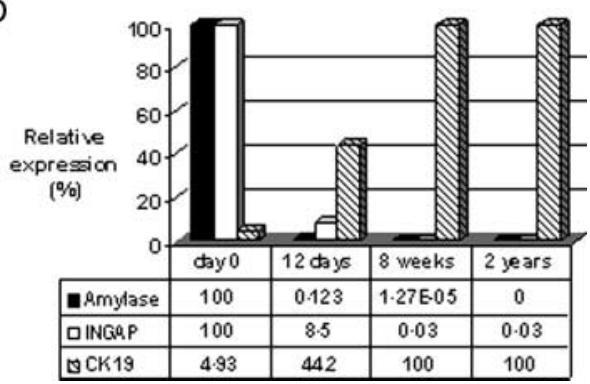

Figure 2 Acinar-to-ductal transdifferentiation in the acinar tissue cultured in collagen. (A) Phasecontrast microphotographs of acinar explants embedded in collagen on day 0. (B) Formation of cavities (arrows) in acinar explants 12 days after embedding. (C) Cysts after 2 years of subculture. Bars are $100 \mu \mathrm{m}$. (D) Relative expression of INGAP, $\alpha$-amylase and CK19 after different periods in culture. Total RNA was isolated and subjected to quantitative real-time RT-PCR as described previously in Materials and Methods. Expression of the indicated genes was normalized to $\beta$-actin. The highest levels of mRNA were taken for $100 \%$ - INGAP and $\alpha$-amylase in the acinar tissue, CK19 - in the cysts.

further cultured for several more months. No decline in cell viability or proliferative capacity during culture has been observed. Cultures are maintained and propagated by regular passaging and splitting the cells 1:5 or 1:10. This process involves fragmentation of the cysts with trypsin followed by re-embedding into collagen, as described under Materials and Methods. Trypsinization generates both single cells and cell clusters containing 2-50 cells, thus resulting in the disappearance of the cystic phenotype (Fig. 3A). New cyst formation from the clusters is observed as early as the next day after passaging and increases progressively in the following days, so that by the end of the first week, culture consists of different-sized cystic structures $(30-500 \mu \mathrm{m})$ of a rather uniform morphology that express CK19 (Figs 3A and $2 \mathrm{C}$ and $\mathrm{D})$.

RT-PCR analysis of the cysts performed throughout the course of the culture period indicated that they express INGAP at a constant level, albeit about 3000 times lower than the original acinar tissue (Fig. 2D). Although freshly isolated acinar explants express higher levels of INGAP mRNA, the utility of this tissue as a model is limited by progressively declining cell viability in vitro (Yuan et al. 1997, Means et al. 2005). In cysts, $C_{\mathrm{t}}$ for INGAP was 26 and for $\beta$-actin was 14 , when cDNA was prepared from $1 \mu \mathrm{g}$ total RNA, which indicates a relatively low but well detectable level of expression. As shown later, cystic structures represent a useful and responsive model for studies on the regulation of INGAP expression. In addition to investigating the effects of growth factors and cytokines, this model also allows the effects of a three-dimensional (3D) organization of a cyst on INGAP expression to be addressed.

Effect of the 3D cyst organization, size, and shape on INGAP $m R N A$

Because monolayer cultures are easier to maintain and analyze, we attempted to grow cells obtained from cysts in monolayers on collagen-coated or non-coated tissue culture plates. Although trypsinized cysts attached and formed a monolayer (passage 0 ), long-term culture was not possible due to replicative senescence observed after the second passage. Furthermore, INGAP expression was completely lost after the first passage (data not shown). This indicates that the 3D organization of the cysts is required for cell proliferation and INGAP expression in the constituent cells. Additional evidence supporting the importance of a 3D tissue organization for INGAP expression in this system comes from the qRT-PCR analysis of cysts sampled at different times after passaging, indicating that the level of INGAP mRNA drops approximately fourfold immediately following the trypsinization, when the 3D structure is disrupted, and that it gradually returns to the initial level as new cysts form and increase in size (Fig. 3C). Since INGAP expression is normalized to $\beta$-actin in this and other experiments, the 
A
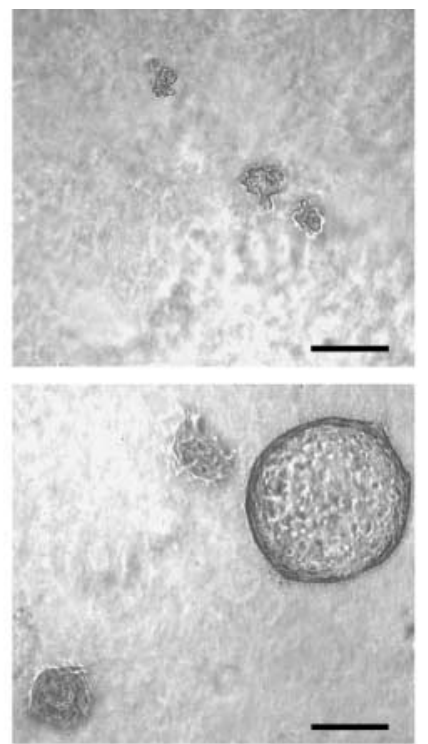

B

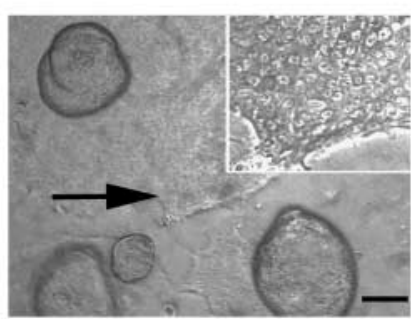

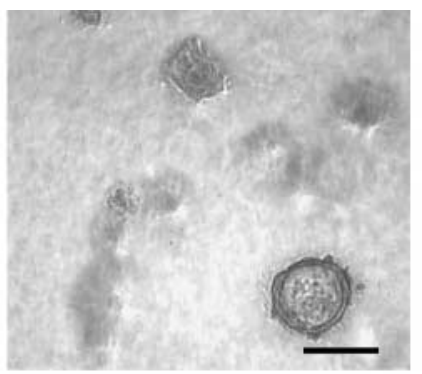

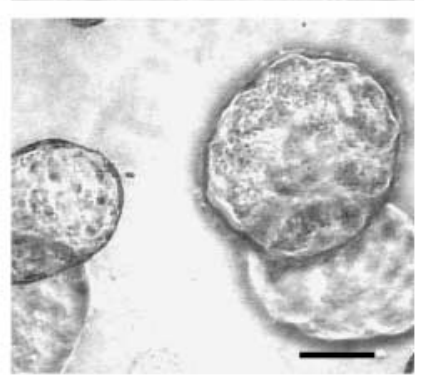

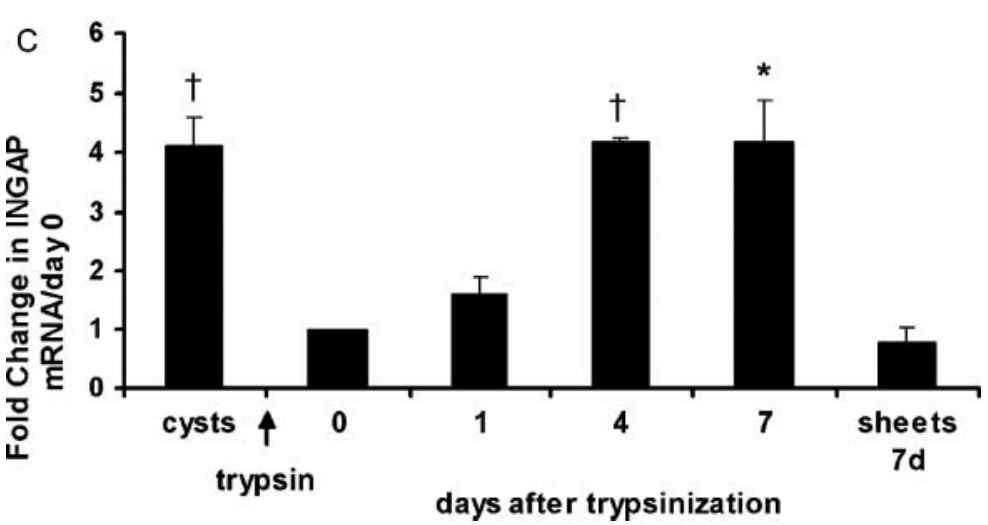

Figure 3 Change in INGAP mRNA level associated with passaging of acinar-derived cystic structures. (A) Phase-contrast microphotographs of cultures embedded into collagen taken at different intervals after passaging. Cystic structures were harvested with collagenase XI, trypsinized for $2 \mathrm{~min}$ and embedded in collagen type-1, as described in Materials and Methods. Trypsinization generates small cell clusters (day 0). Re-appearance of the cystic phenotype is observed starting on day 1 ; cysts progressively increase in size by day 7 . Bars are $100 \mu \mathrm{m}$. (B) A phase-contrast microphotograph of a 7-day-old culture containing cysts and 2D sheets of cells spread underneath collagen (arrow and inset). (C) Fold change in INGAP expression 1, 4, and 7 days after trypsinization, as compared with day 0. Total RNA was isolated and subjected to quantitative realtime RT-PCR as described previously. Data are expressed as a fold change in INGAP mRNA relative to day 0 (equals 1 ) after normalization to $\beta$-actin using the formula $2^{-\Delta \Delta C_{t}}$ and are means \pm S.E.M. ${ }^{*} P<0 \cdot 05,{ }^{+} P<0 \cdot 01$, in comparison with day $0 . d$, day. 
possibility that the observed differences in INGAP mRNA are due to the differences in cell numbers associated with trypsinization and re-growth of the cysts is excluded.

In some instances, newly embedded cell clusters sink to the bottom of a plate and spread beneath the collagen forming sheets of densely packed cells (Fig. 3B). Interestingly, INGAP mRNA levels in the sheets, cultured for 7 days, remained low compared with that of the re-grown cysts (Fig. 3C), thus providing further support for the effect of a 3D tissue organization on INGAP expression.

When cysts are removed from collagen, they usually retain their inflated shape for approximately $1 \mathrm{~h}$ if left in suspension, after which they fold into smaller spherical structures with a very small lumen (Fig. 4A and B). This reflects the intraluminal fluid pressure that increases during cyst growth in collagen, which is then lost when cysts are removed from collagen. To determine if the pressure-associated shape of cysts is a factor in regulation of INGAP expression, we assessed levels of INGAP mRNA in freshly isolated cysts and in collapsed cysts sampled 2, 4, 6, and $24 \mathrm{~h}$ after removal from collagen. As shown in Fig. 4C (solid line and black squares), levels of INGAP mRNA in collapsed cysts decreased approximately $2 \cdot 5$-fold after $4 \mathrm{~h}$ and remained at that level at $24 \mathrm{~h}$. To investigate whether cyst collapsing affects INGAP mRNA stability, these experiments were repeated in the presence of $5 \mu \mathrm{g} / \mathrm{ml}$ actinomycin D (AD) to block transcription. The effectiveness of this dose of $\mathrm{AD}$ was confirmed by observing a rapid degradation of c-myc mRNA in the same samples (data not shown). The similarity of curves obtained in the presence (Fig. 4C, open squares) and absence of $\mathrm{AD}$ (black squares) indicates that the inhibition of INGAP transcription observed upon removal from collagen is related to cyst collapse and the ensuing loss of intra-luminal pressure. As shown, the half-life of INGAP mRNA in these conditions
A

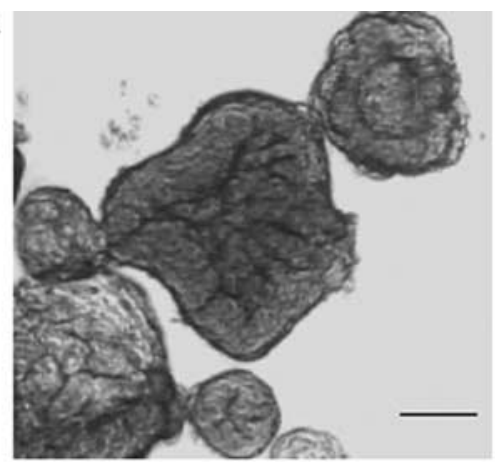

B

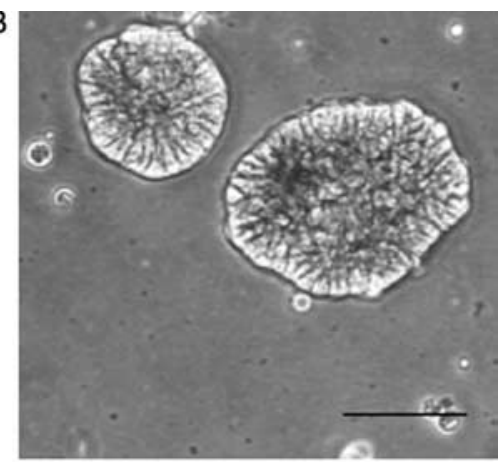

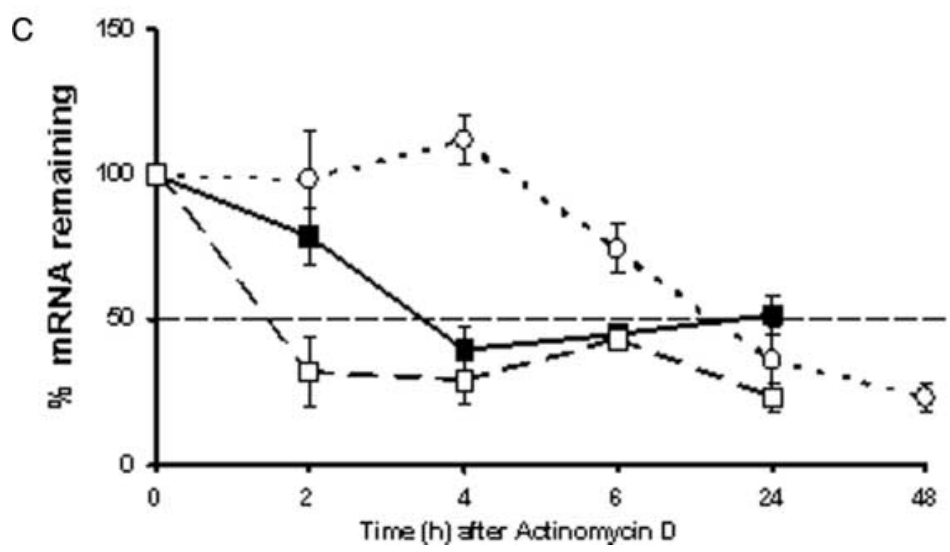

Figure 4 Change in INGAP mRNA levels in collapsed cysts after removal from collagen. (A) and (B) Phase-contrast microphotographs of cysts maintained in suspension for 6 and $24 \mathrm{~h}$ following collagen digestion with collagenase XI, as described in Materials and Methods. Cyst collection and all washes were carried out by allowing cysts to precipitate to the bottom of a tube for 5 min under gravity, followed by aspiration of supernatant. (C) Time course of changes in INGAP mRNA levels following removal from collagen carried out in the presence (open squares) or absence (black squares) of actinomycin $D(A D)$ for the times indicated. For comparison, the time course of INGAP mRNA decay in the cysts cultured in collagen throughout the AD treatment (up to $48 \mathrm{~h}$ ) is shown (circles). Total RNA from collected cysts was isolated and subjected to quantitative real-time RT-PCR as described previously. Values were calculated after normalization to $\beta$-actin using the formula $2^{-\Delta \Delta C_{t}}$ and are presented as percentage of mRNA remaining relative to value at $0 \mathrm{~h}$ (equals $100 \%$ ) and are means \pm S.E.M. 

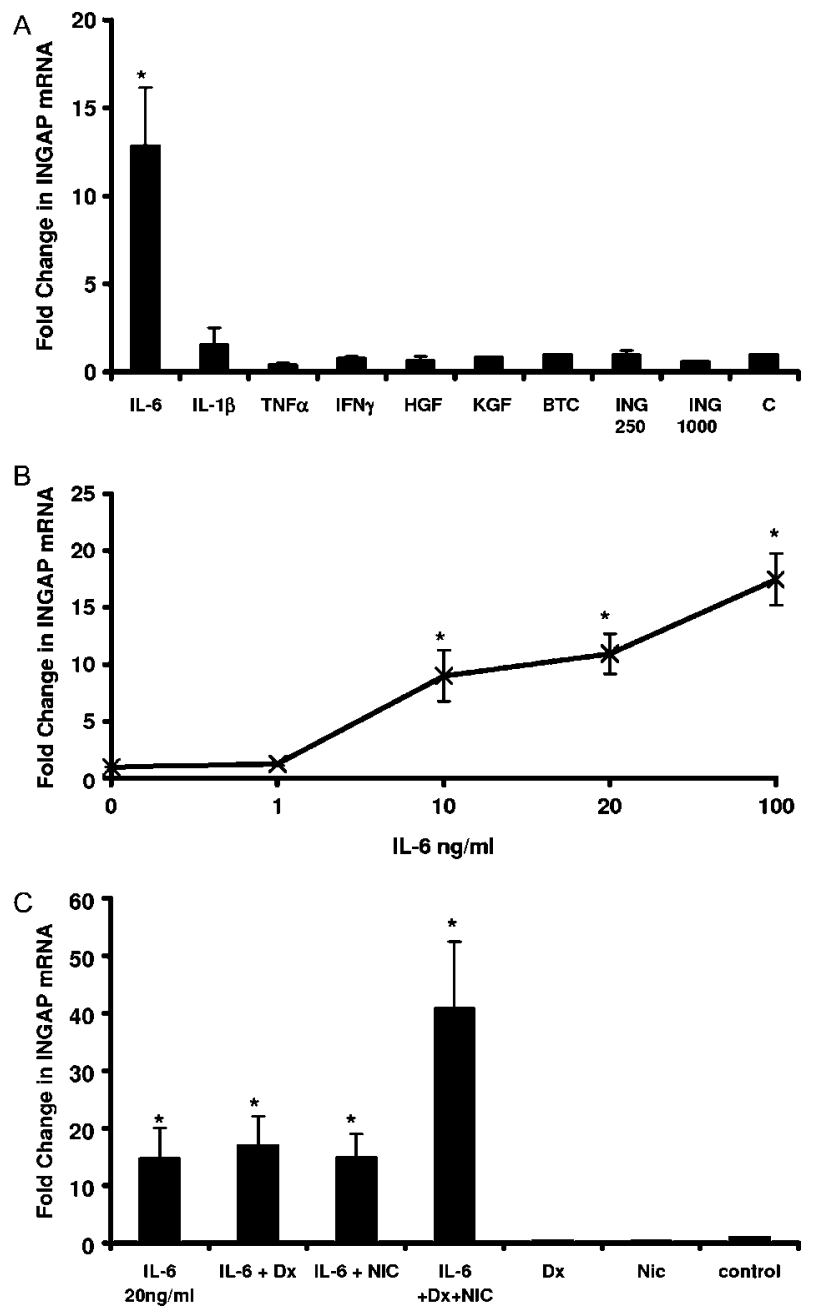

Figure 5 qRT-PCR analysis of INGAP mRNA levels in response to cytokine and growth factor stimulation for $24 \mathrm{~h}$. (A) Effect of cytokines and growth factors on INGAP gene expression. Cysts embedded in collagen were treated with the indicated growth factors and cytokines for $24 \mathrm{~h}$. Following collagen digestion with collagenase $\mathrm{XI}$, cysts were collected, washed and processed for RNA extraction as described in Materials and Methods. Total RNA was reverse transcribed and subjected to quantitative realtime RT-PCR as described previously. Data are expressed as a fold change in INGAP mRNA relative to untreated control (equals 1) after normalization to $\beta$-actin using the formula $2^{-\Delta \Delta C_{\mathrm{t}}}$ and are means \pm S.E.M. ${ }^{*} P<0 \cdot 01$, in comparison with control ( $t$-test). (B) Dose-dependent stimulation of INGAP expression by IL-6. Cysts were treated with the indicated doses of IL-6 for $24 \mathrm{~h}$. Total RNA was isolated and subjected to quantitative real-time RT-PCR as described previously ${ }^{*} P<0 \cdot 01$ in comparison with control (ANOVA). Adjusted differences between 0 and $10 \mathrm{ng} / \mathrm{ml}$ IL-6 $(P=0 \cdot 004), 20 \mathrm{ng} / \mathrm{ml}(P=0 \cdot 001)$, and $100 \mathrm{ng} / \mathrm{ml}(P=$ $0 \cdot 001)$; between $1 \mathrm{ng} / \mathrm{ml}$ and $10 \mathrm{ng} / \mathrm{ml}(P=0 \cdot 006), 20 \mathrm{ng} / \mathrm{ml}$ $(P=0.001)$, and $100 \mathrm{ng} / \mathrm{ml}(P=0.001)$, as well as between 20 and $100 \mathrm{ng} / \mathrm{ml}(P=0.012)$ were found significant by Tukey's LSD analysis. (C) Effect of combined treatment of IL-6 (20 ng/ml) with Dx $(100 \mathrm{nM})$ and NIC $(10 \mathrm{mM})$ on INGAP mRNA. Total RNA was isolated and subjected to quantitative real-time RT-PCR as described previously. ${ }^{*} P<0 \cdot 01,{ }^{+} P<0.05$ in comparison with control ( $t$-test). is approximately $3 \cdot 5 \mathrm{~h}$, which is substantially shorter than in the cysts cultured in collagen (18-20 h; Fig. 4C, open circles). Therefore, these results show that removal from collagen and loss of intra-luminal pressure not only inhibits the INGAP gene transcription, but also increases the rate of INGAP mRNA degradation.

The notion that intra-luminal pressure is indeed involved in the regulation of INGAP expression is further supported by the following additional observation. Due to a certain disparity in size of the cell clusters caused by trypsinization, cysts in 7-day-old cultures vary from 30 to $500 \mu \mathrm{m}$ in diameter. We found that INGAP expression varied with cyst size, being $8 \cdot 32 \pm 0 \cdot 52$ times higher in big cysts $(>94 \mu \mathrm{m}$ in diameter) than in small cysts $(<46 \mu \mathrm{m})$. When isolated small cysts were allowed to grow for a longer time and reach at least $94 \mu \mathrm{m}$ in diameter, levels of INGAP mRNA increased (data not shown), indicating that the observed differences in the level of INGAP mRNA can indeed be attributed to the difference in size. Although it was not possible to measure intra-luminal pressure in small and big cysts, increase in the cyst diameter is, clearly, driven by increase in the pressure, so that the resulting net force is sufficient to compress the collagen wall.

While the factors involved in the size- and pressuredependent regulation of INGAP expression are not yet known, it is important to take this phenomenon into account in the studies on INGAP expression in this system. To minimize the possible fluctuations in INGAP expression that would be unrelated to the experimental treatment, all experiments described below were carried out on the 5- to 7-day-old cultures, passaged and maintained in a consistent manner, and each experiment was performed in duplicate or triplicate on cells from the same passage.

\section{Effect of cytokines and GF on INGAP expression}

Expression of several members of the Reg family of genes is influenced by a number of inflammatory cytokines (Dusetti et al. 1995, 1996, Akiyama et al. 2001). To determine if INGAP expression was similarly regulated, we have tested the effect of several cytokines (IL-6, IL-1 $\beta$, TNF $\alpha$ and IFN $\gamma$ ) administered to the hamster pancreatic cysts for $24 \mathrm{~h}$, as described under Materials and Methods. In addition, we evaluated the effect of several growth factors, such as HGF, BTC, KGF, TGF $\beta 1$, and insulin that have been implicated in the control of pancreatic development, function, and regeneration (Sumi \& Tamura 2000, Kim \& Hebrok 2001). Also, to test whether INGAP expression could be autoregulated by INGAP itself, hamster cysts were treated with INGAP ${ }^{104-118}$ peptide and recombinant INGAP protein.

Changes in expression of INGAP mRNA were evaluated by qRT-PCR. Fold changes in INGAP mRNA, normalized to $\beta$-actin were calculated relative to the expression in the untreated control. Results, summarized in Fig. 5A, show that INGAP expression is differentially regulated. Thus, out of several inflammatory cytokines tested, only IL-6 administered 
at $20 \mathrm{ng} / \mathrm{ml}$ strongly increased INGAP expression $(12 \cdot 85-$ fold) relative to untreated control, while treatments with IL-1 $\beta(200 \mathrm{ng} / \mathrm{ml})$ and IFN $\gamma(100 \mathrm{ng} / \mathrm{ml})$ were ineffective. In contrast, treatment with $\mathrm{TNF} \alpha(100 \mathrm{ng} / \mathrm{ml})$ reduced INGAP expression about twofold. No changes in INGAP mRNA levels were observed when cysts were treated with KGF $(20 \mathrm{ng} / \mathrm{ml})$, HGF $(20 \mathrm{ng} / \mathrm{ml})$, betacellulin $(20 \mathrm{ng} / \mathrm{ml})$, INGAP-peptide (250 and $1000 \mathrm{ng} / \mathrm{ml}$; Fig. 5A), INGAP $(2 \cdot 5,10,50$, and $100 \mathrm{ng} / \mathrm{ml})$, insulin $(5,20,50$, and $100 \mathrm{mU} / \mathrm{ml}$ ), TGF $\beta 1$ (100 pM, data not shown), or $20 \mathrm{mM}$ glucose (data not shown).

The stimulatory effect of IL-6 on INGAP mRNA was dosedependent (Fig. 5B). While $1 \mathrm{ng} / \mathrm{ml}$ IL-6 was ineffective, higher concentrations of IL-6 produced a statistically significant linear increase in INGAP mRNA, as shown by ANOVA $\left(F_{4,24}=16 \cdot 6 ; P=0 \cdot 001\right)$ and linear regression analysis (parameter estimate (S.E.) $=0 \cdot 145(0 \cdot 025) ; \quad P=$ $0 \cdot 001)$. In addition, Tukey's LSD analysis for multiple comparisons showed significant adjusted differences between 0 and $10 \mathrm{ng} / \mathrm{ml} \mathrm{IL-6}(P=0 \cdot 004), 20 \mathrm{ng} / \mathrm{ml}(P=0 \cdot 001)$, and $100 \mathrm{ng} / \mathrm{ml}(P=0 \cdot 001)$; between 1 and $10 \mathrm{ng} / \mathrm{ml}(P=0 \cdot 006)$, $20 \mathrm{ng} / \mathrm{ml}(P=0 \cdot 001)$, and $100 \mathrm{ng} / \mathrm{ml}(P=0 \cdot 001)$, as well as between 20 and $100 \mathrm{ng} / \mathrm{ml}(P=0 \cdot 012)$.
This result is not unexpected, given the presence of IL-6 responsive elements in the promoters of several Reg and HIP/PAP genes (Dusetti et al. 1995, Abe et al. 2000, Nata et al. 2004). Interestingly, IL-6 has been reported to stimulate expression of human HIP/PAP gene (Gurr et al. 2002), but had no effect on expression of rat PAP1 and Reg1 genes when administered alone (Dusetti et al. 1996, Akiyama et al. 2001). Co-administration of Dx was required for induction of both rat PAP1 and Reg1 genes, which in the case of Reg1 was further enhanced by treatment with NIC.

Accordingly, we then sought to determine if INGAP expression could be further upregulated by combinations of IL-6, Dx, and NIC. As shown in Fig. 5C, addition of either Dx or NIC alone did not change the effect of IL-6 on INGAP expression but the combined addition of all three agents strongly upregulated (up to 41-fold) levels of INGAP mRNA. The stimulatory effect of IL-6 alone or in combination with Dx and NIC was observed as early as $3 \mathrm{~h}$ after the treatment (Fig. 6A), suggesting that IL-6 was acting at the transcriptional level.

To determine if this effect was indeed mediated at the transcriptional level, cultures were treated with $5 \mu \mathrm{g} / \mathrm{ml}$ actinomycin D. Addition of AD completely blocked the

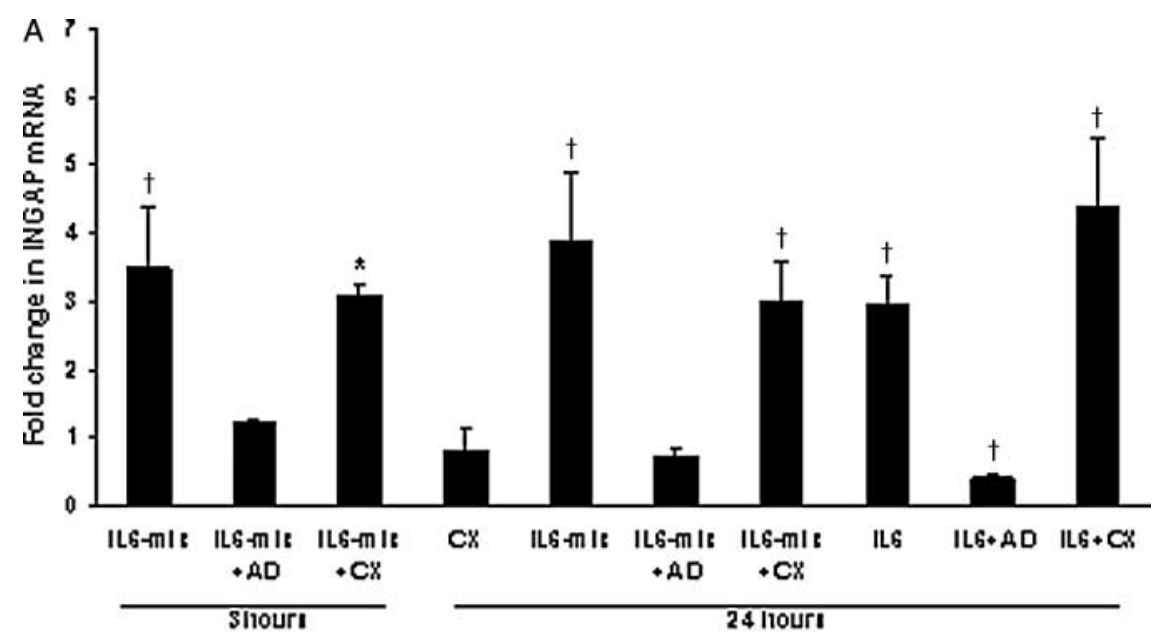

B

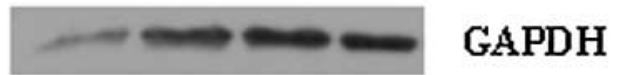

\section{$\begin{array}{lllll}10 & 5 & 1 & 0 & \mathrm{CX}(\mu \mathrm{g} / \mathrm{ml})\end{array}$}

Figure 6 Effect of IL-6 $(20 \mathrm{ng} / \mathrm{ml})$ alone and in combination with Dx $(100 \mathrm{nM})$ and NIC $(10 \mathrm{mM})$ for 3 and $24 \mathrm{~h}$ incubation in the presence of $\mathrm{AD}$ and cycloheximide (CX). (A) Effect of IL-6 on INGAP expression is mediated at the transcriptional level and does not depend on neo-protein synthesis. AD $(5 \mu \mathrm{g} / \mathrm{ml})$ and $\mathrm{CX}(10 \mu \mathrm{g} / \mathrm{ml})$ were added for the indicated times to inhibit transcription and translation respectively. Combination of IL-6, Dx, and NIC is denoted as IL-6 mix for brevity. Data are expressed as a fold change in INGAP mRNA relative to untreated control (equals 1 , data not shown) after normalization to $\beta$-actin using the formula $2^{-\Delta \Delta C_{t}}$ and are means \pm S.E.M. $* P<0 \cdot 01,{ }^{\dagger} P<0.05$ in comparison with control. (B) Dose-dependent inhibition of protein synthesis by CX. One-hundred micrograms protein from total cell lysates of the cysts treated with 1,5 , and $10 \mu \mathrm{g} / \mathrm{ml} \mathrm{CX}$ were resolved on SDS-PAGE, transferred on nitrocellulose membrane and probed with anti-GAPDH antibody. 
effect of IL-6 administered alone or in combination with Dx and NIC (IL-6 mix) either after 3 or $24 \mathrm{~h}$ (Fig. 6A), which is indicative of the regulation on the transcriptional level. Based on a $2 \cdot 5$-fold decrease in the amount of INGAP transcripts remaining in the IL-6+AD-treated cysts after $24 \mathrm{~h}$ (significant at $P<0 \cdot 05$ ), which is similar to the values presented in Fig. 4, IL-6 does not influence half-life of INGAP mRNA. It is possible, however, that the addition of Dx and NIC to IL-6 (IL-6 mix) slightly increases INGAP mRNA stability, as the amount of remaining INGAP transcripts in this group was not significantly different from control (Fig. 6A). More detailed experiments are needed to examine this possibility. To verify whether the stimulatory effect of IL-6 on INGAP expression required neo-protein synthesis, cysts were treated with $10 \mu \mathrm{g} / \mathrm{ml}$ cycloheximide (CX; Sigma) added $2 \mathrm{~h}$ before, and during the treatment with IL-6 alone or with IL-6 mix. Effective inhibition of translation by $\mathrm{CX}$ administered at this dose was proven by significant reduction in the amount of GAPDH protein detected by immunoblotting of samples treated with different doses of CX for $24 \mathrm{~h}$ (Fig. 6B). As shown in Fig. 6A, CX did not reduce the expression of INGAP mRNA either after 3 or $24 \mathrm{~h}$, thus providing further evidence that IL-6 regulates INGAP expression directly, at the transcriptional level. It should be noted that the effect of IL-6 mix on INGAP expression in this experiment and in the data presented below was more modest (fourfold increase), as compared with the earlier findings (Fig. 5). This is most likely due to a different lot of IL-6 being used in these experiments.

\section{Signaling pathways involved in IL-6-mediated increase in INGAP $m R$ RA}

IL-6 evokes a number of diverse responses in different cells via the IL-6 receptor, which consists of an IL-6-binding molecule called IL-6R $\alpha$ and gp130, a common signal transducing subunit of the IL-6 family of receptors (Ishihara \& Hirano 2002). Ligand binding to IL-6R $\alpha$ induces heterodimerization of the receptor subunits and activates two major signal transduction pathways mediated by JAK/STAT and SHP-2/Gab/MAPK respectively (Ishihara \& Hirano 2002). We investigated whether treatment with IL-6 alone or in combination with Dx and NIC affects expression of the proteins involved in the IL-6-initiated signaling pathway. qRT-PCR analysis showed no change in expression of IL-6R $\alpha$, GP-130, Jak1, Jak2, STAT1, and STAT2 genes in response to any of the treatments, but demonstrated a 2to $2 \cdot 5$-fold increase in STAT3 mRNA in response to IL-6 alone or in combination with Dx and NIC (Fig. 7A). The increase in mRNA correlated with an increase in STAT3 protein observed after $24 \mathrm{~h}$ treatment (Fig. 7B). To investigate the role of JAK/ STAT3 pathway in increasing INGAP mRNA, we used several inhibitors of JAK/STAT signaling pathway: a new selective inhibitor of JAK/STAT3, cucurbitacin $1(\mathrm{Cu})(1$ and $10 \mu \mathrm{M}$, Calbiochem) shown to inhibit STAT3 activation, STAT3 DNA-binding activity, and STAT3-mediated gene transcription without inhibiting activities of p44/42MAPK, JNK,
Akt, and Src (Blaskovich et al. 2003, Nefedova et al. 2005); a potent inhibitor of the JAK family protein kinases, JAK inhibitor 1 (J1) (10 nM, Calbiochem; Thompson et al. 2002); and a specific inhibitor of JAK2, tyrphostin AG-490 $(100 \mu \mathrm{M}$, Sigma). As shown in Fig. 8A, the treatment of cysts for $3 \mathrm{~h}$ with $10 \mathrm{nM}$ Jak inhibitor 1,1 and $10 \mu \mathrm{M} \mathrm{Cu}$ but not with $100 \mu \mathrm{M}$ AG-490, resulted in a significant decrease of the base level of INGAP mRNA. No changes in expression of $\beta$-actin have been detected. Interestingly, the inhibition of STAT3 with $10 \mu \mathrm{M} \mathrm{Cu}$ completely abolished the stimulatory effect of IL- 6 used alone or in combination with Dx and NIC on INGAP mRNA levels, while $1 \mu \mathrm{M} \mathrm{Cu}$ was effective only on IL-6-treated cysts. The inhibitory effect of AG-490 was not significant, whereas J1 significantly inhibited the IL-6 mix-stimulated INGAP expression (Fig. 8A). A similar pattern of inhibition was observed after $24 \mathrm{~h}$ treatment (Fig. 8B), except for almost complete abolition of INGAP expression by $\mathrm{Cu}$. It should be noted that this effect might be due to inhibition of cell growth and cytotoxicity observed in the Cu-treated cultures after $24 \mathrm{~h}$, but not after $3 \mathrm{~h}$. No adverse effects were observed in the J1 and AG-490-treated cultures. These data clearly indicate that the JAK/STAT3 pathway plays an important role in the regulation of INGAP expression. They also suggest that JAK2 is not a major transducer of the IL-6-induced increase in INGAP expression, thereby implicating other members of JAK family, likely JAK1 in this signal transduction mechanism.

We next tested whether signaling proteins, such as $\mathrm{p} 44 / 42$ MAPK, p38 MAPK, which have been implicated in IL-6 signaling (Zauberman et al. 1999, Ishihara \& Hirano 2002) and JNK may play a role in the upregulation of INGAP expression. First, we assessed phosphorylation of p38 MAPK, JNK, and p44/42MAPK by western blot analysis and found an increase in phosphorylation of p38 MAPK, but only a slight increase in p44/42MAPK phosphorylation after treatment with IL-6 (alone or in combination; Fig. 9A, lanes 1 and 2). No phosphorylation of JNK was detected (data not shown), which is consistent with observations of others (Zauberman et al. 1999, Ishihara \& Hirano 2002). To determine if these kinases contributed to the observed stimulation of INGAP by IL-6, cysts were pretreated with the respective pharmacological inhibitors $1 \mathrm{~h}$ before the cocktail of IL-6 $20 \mathrm{ng} / \mathrm{ml}$, Dx $100 \mathrm{nM}$, and NIC $10 \mathrm{mM}$ was added for $24 \mathrm{~h}$. As shown in Fig. 9A, U0126 $(10 \mu \mathrm{M})$ inhibited activation of p44/42MAPK (lane 5) and SB203580 $(10 \mu \mathrm{M})$ inhibited P38 but, surprisingly, also activated p44/ 42MAPK (lane 3). The phenomenon of p44/42MAPK activation by SB203580 or SB202190 has already been reported in a variety of cell lines (Birkenkamp et al. 2000, Kakisis et al. 2005), but its mechanism remains unclear. Since the inhibition of p38 MAPK with SB203580 $(10 \mu \mathrm{M})$ did not significantly influence basal INGAP mRNA (Fig. 9B), activation of $\mathrm{p} 44 / 42$ MAPK did not seem to play an important role in INGAP expression. Similar to p38, the inhibition of JNK with SP600125 $(10 \mu \mathrm{M})$ had no effect on 

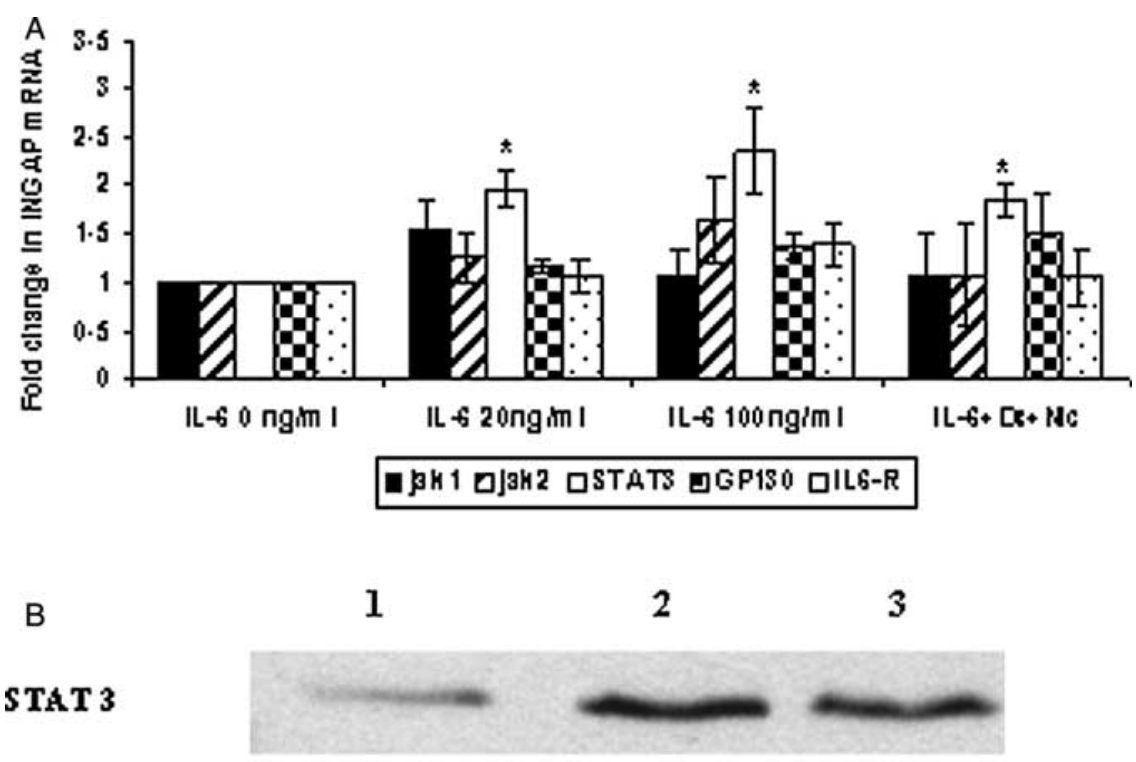

\section{GAPDH}

Figure 7 Effect of IL-6 administered alone or in combination with Dx (100 nM) and NIC (10 mM) on expression of proteins involved in the IL-6 signaling cascade. (A) qRT-PCR analysis of expression of IL-6R $\alpha$, Gp130, Jak1 and 2, and STAT3 in the cysts treated with IL-6 alone or in combination with Dx and NIC. Cells were treated for $24 \mathrm{~h}$, harvested and processed for total RNA isolation as described previously. Data are expressed as a fold change in INGAP mRNA relative to untreated control (equals 1 ) after normalization to $\beta$-actin using the formula $2^{-\Delta \Delta C_{t}}$ and are means \pm S.E.M. $* P<0 \cdot 05$. (B) Western blot analysis of STAT3 protein in the control cysts (lane 1 ), and cysts treated with IL-6 $20 \mathrm{ng} / \mathrm{ml}$ (lane 2) or with combination of IL-6, Dx, and NIC. Onehundred micrograms protein from total cell lysates were resolved on SDS PAGE, transferred on nitrocellulose membrane and probed with anti-STAT3 antibody. Blots were stripped and re-probed with GAPDH antibody as a control of protein loading.

INGAP expression. In contrast, the p44/42 MAPK inhibitor, U0126, increased INGAP mRNA $3 \cdot 78$-fold. None of the inhibitors tested significantly influenced stimulation of INGAP gene expression by IL-6 mix.

\section{Discussion}

In this paper, we report the establishment of the first in vitro model of INGAP expression derived from hamster pancreatic acinar tissue. To the best of our knowledge, no other in vitro models of expression of INGAP or any other Reg3 protein have been described. The objective of the present study was to characterize INGAP expression in this model, to compare it with acinar tissue and to investigate its responsiveness to pro-inflammatory cytokines and a number of growth factors.

This model consists of 3D duct-like epithelial cystic structures derived from isolated acinar tissue through the process of acinar-to-ductal transdifferentiation that is characterized by loss of amylase and upregulation of the duct-epithelial cell marker CK19. Here, we demonstrate that the resulting cystic structures can be propagated for many months in collagen matrix maintaining a transdifferentiated ductal phenotype. Although maintenance and experimental manipulations of 3D cultures are more complex than those of 2D monolayers, utility of 3D cultures for systematic analysis of molecular pathways underlying various physiological events has been proven in numerous studies (for review, see Schmeichel \& Bissell 2003). Furthermore, numerous studies have suggested that $3 \mathrm{D}$ cultures approximate in vivo situations better than monolayer cultures (for review, see Birgersdotter et al. 2005, Schmeichel \& Bissell 2003). As a first step, in the present work, we tested the utility and limitations of this model for studies on INGAP expression.

In the pancreas, acinar tissue is the main source of INGAP, although INGAP expression has also been found in islets and ducts, as shown in this study and by others (Del Zotto et al. 2000, Flores et al. 2003). The growth factors, signaling pathways, and transcription factors implicated in maintaining a high level of INGAP expression in acinar tissue are not known. These factors appear to be lost when acini transdifferentiate into duct-like cystic structures, which results 

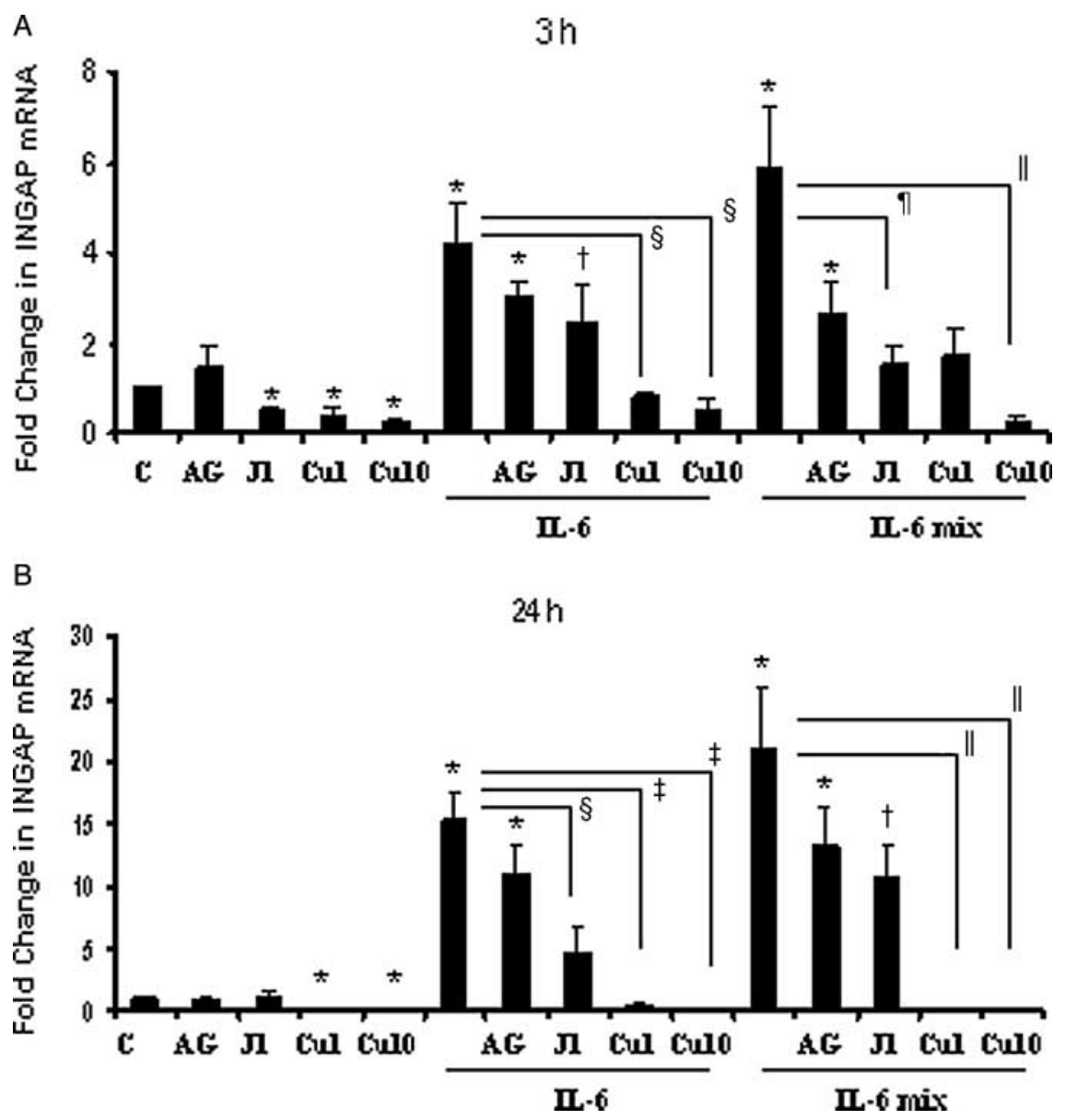

Figure 8 Effect of JAK/STAT3 inhibitors cucurbitacin I (Cu), JAK inhibitor 1(J1) and JAK2 inhibitor AG-490 (AG) on INGAP expression. Cysts were pretreated with 1 or $10 \mu \mathrm{M} \mathrm{Cu}(\mathrm{Cu} 1, \mathrm{Cu} 10)$, $10 \mathrm{nM} \mathrm{J1}$, and $100 \mu \mathrm{M}$ AG for $1 \mathrm{~h}$ before addition of $20 \mathrm{ng} / \mathrm{ml} \mathrm{IL-}-6$ or IL-6 + Dx + NIC (IL-6 mix) and were further incubated for 3 and $24 \mathrm{~h}$ (A and B respectively). Total RNA was isolated and subjected to quantitative real-time RT-PCR as described previously. Data are expressed as a fold change in INGAP mRNA relative to untreated control (equals 1 ) after normalization to $\beta$-actin using the formula $2^{-\Delta \Delta C_{\mathrm{t}}}$ and are means \pm s.E.M. ${ }^{*} P<0 \cdot 01 ;{ }^{\dagger} P<0 \cdot 05$ in comparison with control; ${ }^{\ddagger} P<0 \cdot 01 ;{ }^{\S} P<0 \cdot 05$ in comparison with the IL-6 treated cells; $P<0 \cdot 01 ;{ }^{q} P<0.05$ in comparison with the IL-6 mix-treated cells.

in a significant reduction (3000 times) in INGAP expression. However, the levels of INGAP mRNA appear to remain relatively constant once the transdifferentiation has been completed. This suggests that key transcription factors involved in expression of the INGAP gene remain in place. Furthermore, our data show that INGAP expression in this system is responsive to a variety of stimuli indicating the existence of the appropriate receptors and signaling pathways. These data, together with the expandability of cysts in vitro and the presence of an intact INGAP promoter, suggest that the cystic structures described here may serve as a useful model in studies on the regulation of INGAP expression, as well as other Reg family members.

This is the first study to examine INGAP mRNA stability on the basis of actinomycin D chase experiments. We demonstrate that in the cysts maintained in collagen INGAP mRNA has a long half-life of approximately $18-20 \mathrm{~h}$. This result is consistent with the lack of apparent destabilizing sequence determinants within $3^{\prime}$ - and $5^{\prime}$-untranslated regions (UTRs) of INGAP mRNA, according to the sequence published by Rafaeloff et al. (1997) that are typical for high-turnover mRNAs (Guhaniyogi \& Brewer 2001). However, we also show that INGAP mRNA can quickly degrade in response to a change in the conditions, as observed in the collapsed cysts removed from collagen. Although the stability of INGAP mRNA in vivo is not known, it can be speculated that because stable transcripts permit a longer translational window, and INGAP is expressed in all parts of the pancreas, it plays an important role not only in pancreatic regeneration, but also has other important functions that are yet to be determined. 

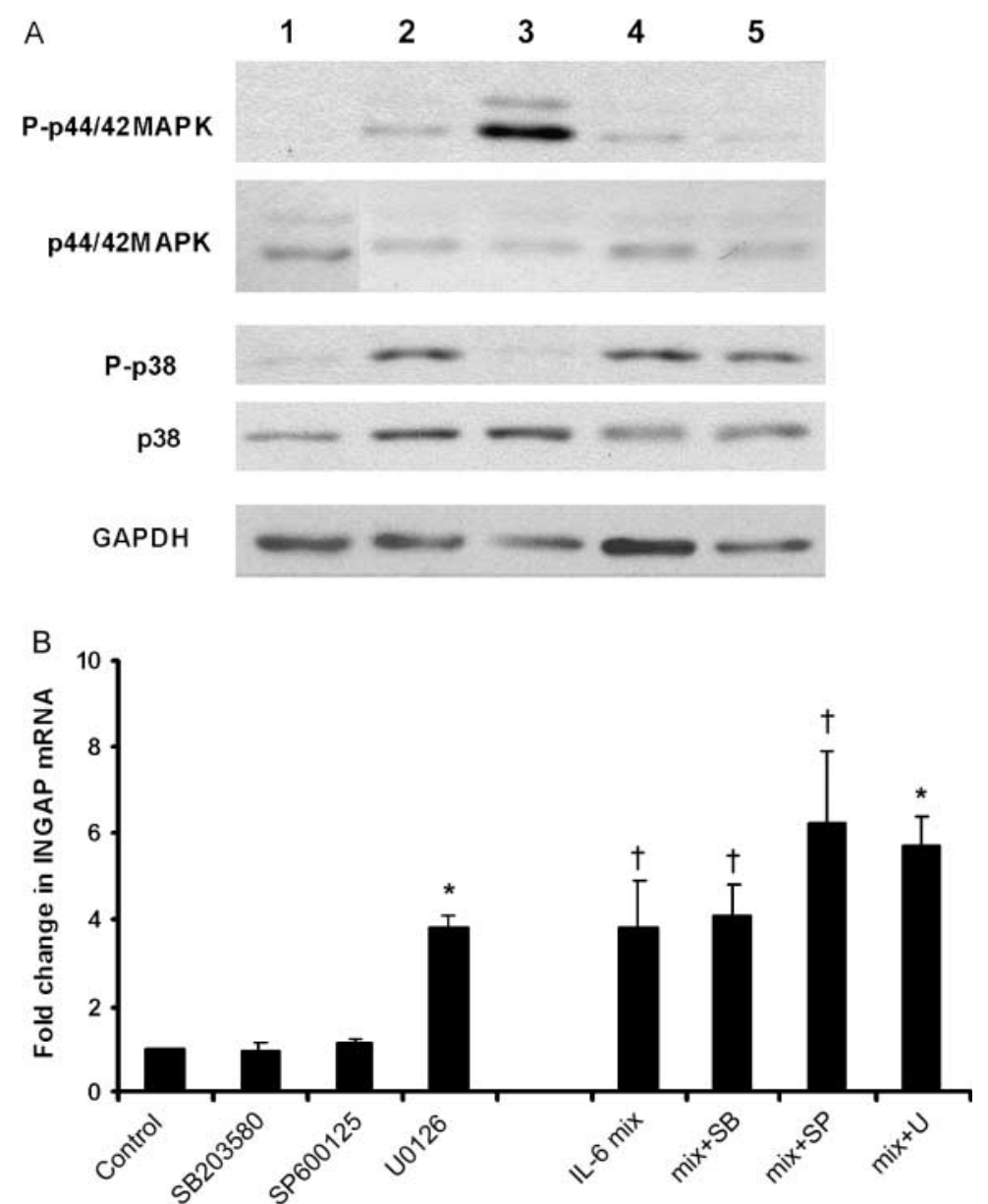

Figure 9 Effect of MAPK inhibitors on MAPK phosphorylation and INGAP expression. Cells were pretreated with $10 \mathrm{mM} \mathrm{SB} 203580$ (SB), SP600125 (SP) and U0126 (U) for $1 \mathrm{~h}$ before addition of IL-6 + Dx + NIC (IL-6 mix) for 24 h. (A) Phosphorylation status of p44/42 MAPK and p38 MAPK in response to IL- 6 mix added alone or with the indicated inhibitors. One-hundred micrograms protein from total cell lysates were resolved on SDS-PAGE, transferred on nitrocellulose membrane and probed with antibodies to p38 MAPK, phosphorylated at Thr180/Tyr182 (P-p38) and non-phosphorylated (p38), p44/42 MAPK phosphorylated at Thr202/Tyr204 (P-p44/42 MAPK) and non-phosphorylated (p44/42 MAPK), and to GAPDH as a control of protein loading. Lane 1, control; lane 2, IL-6 mix; lanes 3-5, IL-6 mix with SB, SP and U respectively. (B) Effect of MAPK inhibitors on INGAP expression. Cells were treated with the indicated inhibitors, with or without IL-6 mix for $24 \mathrm{~h}$. Significant increase in INGAP mRNA is observed after treatment with U0126 alone and with IL-6 mix for $24 \mathrm{~h}$. None of the inhibitors indicated significantly influenced the effect of IL- 6 mix on INGAP expression. Total RNA was isolated and subjected to quantitative real-time RT-PCR as described previously. Data are expressed as a fold change in INGAP mRNA relative to untreated control (equals 1 ) after normalization to $\beta$-actin using the formula $2^{-\Delta \Delta C_{t}}$ and are means \pm s.E.M. ${ }^{*} P<0 \cdot 01,{ }^{\dagger} P<0 \cdot 05$ in comparison with control.

An important advantage of a $3 \mathrm{D}$ system over a $2 \mathrm{D}$ monolayer is that it allows the influence of $3 \mathrm{D}$ organization and of extracellular matrices on gene expression to be addressed. Thus, our data show that INGAP expression fluctuates several fold when the spatial arrangements of cells in the growing cysts change. Moreover, the maintenance of a 3D tissue architecture and microenvironment of a cyst have a dramatic impact on proliferation and INGAP expression in these primary cells that undergo replicative senescence and lose INGAP expression when cultured in monolayers.

Dramatic differences in cell behavior in 3D matrices versus 2D monolayer cultures have been observed for both normal and malignant cells in many studies (for review, see Hay 1993, Yamada et al. 2003). A unique feature of 3D matrix cultures is that they restore apical-basal cell polarity absent in 2D monolayers. Polarity is a fundamental property of epithelium 
that regulates intracellular and extracellular proliferative signaling, differentiation, and responsiveness to growth factors (for review, see Bilder 2004, Liu et al. 2005). Polarization of epithelial cells in matrix-embedded tissues is characterized by formation of basal lamina, apical junctions, and a lumen, thus resembling cystic structures, and is accompanied by tissuespecific differentiation and appearance of vectorial secretion, e.g. milk in mammary cultures and prostate specific antigen (PSA) in prostate epithelial cells (Barcellos-Hoff et al. 1989, Ma et al. 1997).

Cystic structures in our culture system rapidly increase in diameter (approximately tenfold in 7 days), which is indicative of both cell proliferation and secretion of fluids in a luminal direction. Significance of vectorial secretion for INGAP expression and the nature of factors being secreted are not known. Mechanical forces arising during this process have not been characterized, but flattening of epithelium and continuous distention of the cystic wall are suggestive of an increasing pressure from inside. It is possible that continuous vectorial secretion of fluids creates an increased intra-luminal pressure, which in turn is responsible for the increase in INGAP mRNA. It is also possible, however, that the increase in INGAP mRNA in the growing cysts is not caused by pressure alone, but also by a factor(s) secreted and accumulated in the cyst lumen. Further experiments are needed to address these questions.

We observed that INGAP mRNA increases with cyst size but remains low if passaged cells form 2D sheets instead of cysts, despite the fact that they remain in contact with collagen. This suggests that pressure associated with cyst growth in collagen has more impact on INGAP expression than the direct contact with collagen itself. The data showing that cyst collapse following removal from collagen inhibits INGAP transcription and impairs mRNA stability support this notion. However, a synergistic effect of pressure and collagen matrix on regulation of INGAP expression cannot be excluded. Experimentation with other matrices such as alginate hydrogels, engineered with or without cell adhesion ligands, may help to delineate the role of pressure and of the matrix-mediated integrin signaling in regulation of INGAP expression.

A potential role of intra-luminal pressure in regulation of INGAP expression is especially interesting in respect to the history of INGAP discovery on the animal model of partial pancreatic duct obstruction, produced as a result of cellophane wrapping of the pancreas (Rosenberg et al. 1988). While the mechanisms involved in the induction of INGAP gene expression in the partially obstructed pancreas are not known, our previous data (Rosenberg et al. 1988), as well as numerous observations made by others in the ductligated pancreas clearly indicate an increase in the intra-ductal pressure caused by duct obstruction (Abe \& Watanabe 1995, Hamamoto et al. 2002, Boerma et al. 2003). It is tempting to speculate that the pressure associated with cyst growth is comparable to the pressure caused by partial pancreatic duct obstruction. It is possible, therefore, that pressure was one of the driving forces contributing to the activation of INGAP expression in the partially obstructed pancreas.

The signaling events initiated by mechanical stimulation are numerous, depending on the cell type and may include activation of ion channels, generation of second messengers, change of phosphorylation status of proteins, amplification through enzymatic cascades, and transmission via a complicated network of signaling molecules (Liu et al. 1999). Which of these potential mechanisms are involved in cyst growth and how they influence expression of the INGAP gene will be addressed in future experiments. According to the Laplace's law $(T=P R / 2$, where $T$ is a tension of the wall, $P$ is pressure, and $R$ is diameter of a sphere), an increase in pressure would lead to an increase in wall tension or stretch in a growing cyst. Mechanical stretch is one of the most important modulators of cell physiology and is characterized by simultaneous activation of multiple signaling pathways (Liu et al. 1999, Pan et al. 1999). Interestingly, a number of studies implicate the JAK/STAT pathway as one of the major effectors of mechanical stretch on gene transcription in a number of tissues (Pan et al. 1999, Kakisis et al. 2005). Our data demonstrating that inhibition of STAT3 activity by $\mathrm{Cu}$ results in significant reduction of basal levels of INGAP mRNA in the grown cystic structures, may suggest that STAT3 is involved in the pressure-related increase in INGAP expression. Further experiments are required to verify this possibility. It would also be interesting to compare signaling cascades involved in pressure-related increase in INGAP expression in cysts and in the partially obstructed pancreas.

Partial duct obstruction induced by cellophane wrapping is not associated with tissue atropy, diffuse pancreatitis, or lymphocyte infiltration (Rosenberg 1998), thus it appears that in this model INGAP was upregulated in the absence of inflammation, unlike other Reg genes (Reg, PAP1, PAP2, and $P A P 3)$ involved in the acute phase of pancreatitis (Dusetti et al. 1995, 1996). Our data support this notion showing that such pro-inflammatory cytokines as IL- $1 \beta$, IFN $\gamma$, and TNF $\alpha$ did not increase INGAP expression, which is in contrast with the reported stimulatory effects of these cytokines on expression of PAP1 and Reg (Dusetti et al. 1995, 1996). On the other hand, responsiveness of INGAP to IL-6 indicates that INGAP is also sensitive to inflammatory signals.

IL-6 is a pleiotropic cytokine that exerts a wide spectrum of regulatory activities during immune and inflammatory responses and cell growth and differentiation in a number of tissues (Ishihara \& Hirano 2002). It is notable that data on its role in the development of an inflammatory process in the pancreas are contradictory. IL- 6 is believed to be one of the acute phase response cytokines involved in the development of acute pancreatitis (Kingsnorth 1997). However, a number of reports indicate that IL-6 alone does not induce pancreatitis (Suzuki et al. 2000) and on the contrary, protects pancreatic islets or $\beta$-cells from inflammatory, cytokine-induced cell death, both in vitro and in vivo (Choi et al. 2004). Transgenic mice overexpressing IL-6 in $\beta$ cells may or may not develop insulitis but they do not develop pancreatitis or diabetes 
(Campbell et al. 1994, DiCosmo et al. 1994). It is also of note that the overexpression of IL-6 has been associated with islet hyperplasia and an increased number of extra- and intra-islet ducts, suggestive of islet neogenesis in IL-6 transgenic mice (Campbell et al. 1994). Clearly, these changes resemble the events observed in the cellophane wrapping model. Although no inflammation was observed in the cellophane wrapped pancreas, increased expression of certain cytokines, such as IL-6, as the result of the treatment has not been excluded; and it could well be that IL-6 was associated with induced INGAP expression in that model. Another possibility is that INGAP expression was induced by a different factor or by a combination of factors of a non-inflammatory nature, which have not yet been identified. Mechanical forces associated with increase in intra-ductal pressure, as one of these possibilities, were already alluded to earlier.

The effect of IL-6 on INGAP mRNA was further enhanced by addition of Dx and NIC. This effect was detected $3 \mathrm{~h}$ after addition of IL-6, either alone or in combination with Dx and NIC and was inhibited by actinomycin D but not by Cx. This suggests that IL-6, alone or with Dx and NIC, exerts its stimulatory effect at the level of gene transcription and does not depend on protein neo-synthesis. How this occurs is not clear from the present study. Two hexanucleotides, TTCCCAG and CTGGAAA, were identified as IL-6/Dx-responsive elements in the PAP1 promoter (Dusetti et al. 1995), whereas an IL-6/ Dx-responsive element in the Reg1 gene promoter was identified as a 12-mer TGCCCCTCCCAT (Akiyama et al. 2001). Although no reference to the IL-6-responsive elements in the INGAP gene promoter has been made (Taylor-Fishwick et al. 2003), we were able to locate a short fragment (950961 bp; Taylor-Fishwick et al. 2003), which is almost identical to the IL-6/Dx-responsive element in Reg1, except for the last two nucleotides (TC in INGAP, AT in Reg1). This cis-element was found to be responsible for the induction of the Reg gene by IL-6/glucocorticoid, and PARP was shown to bind this ciselement forming the active transcriptional complex for Reg gene expression. NIC enhanced formation of the active transcriptional complex by inhibiting the autopoly (ADPribosyl)ation of PARP (Akiyama et al. 2001). Given the similarity of the elicited responses in gene expression and the regulatory elements in Reg and INGAP promoters, it is very likely that the additive effect of IL-6, Dx, and NIC on INGAP expression is mediated by the same mechanism as for Reg1.

Unlike the Reg1 gene, the expression of INGAP was also upregulated by IL-6 alone and this effect was dose-dependent. This suggests that INGAP has other IL-6-responsive elements on its promoter. IL-6 initiates signal transduction pathways mediated by JAK/STAT and SHP-2/Gab/ERK MAPK cascades (Ishihara \& Hirano 2002). In this study, we investigated whether MAPKs are involved in regulation of INGAP expression by IL-6 and found that pharmacological inhibition of $\mathrm{p} 38$ MAPK and JNK did not influence INGAP expression in the cysts stimulated with a combination of IL-6, Dx, and NIC. This indicates that these kinases are probably not involved in INGAP regulation by IL-6. Interestingly,
U0126, a specific inhibitor of p44/42 MAPK, appeared to upregulate basal INGAP expression, in the absence of IL-6. It is possible that $p 44 / 42$ MAPK regulates the expression of a suppressor of INGAP expression, which might be present in the cystic structures. Therefore, the inhibition of a suppressor protein by inhibiting the p44/42 MAPK pathway may explain the observed upregulation of INGAP mRNA. Another possibility is that U0126 directly activates INGAP promoter, although no information supporting this possibility was found in the literature. Further experiments specifically stimulating or suppressing signaling pathways are required to understand better how INGAP expression is regulated.

We have also investigated the more 'classic' JAK/STAT pathway of IL-6 action. We determined first if the IL-6 effect was mediated via upregulation of mRNA for the IL- 6 receptor (both IL-6R $\alpha$ and gp130), JAK1, JAK2, STAT1, STAT2, and STAT3, the most likely players in the IL-6-initiated signaling cascade. No changes in expression of the IL-6 receptor or JAK1, JAK2, STAT1, and STAT2 were observed. In contrast, changes in STAT3 in response to IL-6, used alone or in combination with Dx and NIC, were observed both on mRNA and protein levels. Experiments with JAK/STAT3 inhibitor $\mathrm{Cu}$ I clearly indicate the involvement of STAT3 in the regulation of INGAP expression, as it significantly reduced both basal and the IL-6-induced levels of INGAP mRNA. To fully implicate STAT3 in the regulation of INGAP expression, further experiments on STAT3 DNA binding are needed. The events leading to STAT activation in response to IL-6 are less clear. $\mathrm{Cu}$ has also been shown to inhibit activation of JAK2 (Blaskovich et al. 2003), but given that a specific JAK2 inhibitor AG-490 did not have a significant effect on INGAP expression, the inhibition of JAK2 was probably not the major component of the observed effect of this inhibitor. The effectiveness ofJAK inhibitor 1 in reduction of INGAP mRNA levels is consistent with a constitutive involvement of the JAK family of protein kinases in cytokine-mediated signaling pathways, although the magnitude of inhibition was not as high as that of $\mathrm{Cu}$. This may indicate that protein kinases other than JAKs are involved in STAT3 activation. Further experiments are needed to fully elucidate the signaling pathways leading to increases in INGAP expression. Taken together, these data indicate the importance of JAK/STAT-signaling pathways in the regulation of INGAP expression and implicate STAT3 as a potential transducer of the IL-6 effect.

In summary, in this study we describe the first in vitro model of INGAP expression. This model is important because it provides an opportunity to investigate the regulation of INGAP expression in response to a variety of stimuli. This is also the first study to address the effects of a 3D culture system, growth factors, and inflammatory cytokines on expression of the INGAP gene. Our results suggest the involvement of multiple regulatory pathways. This is in agreement with the presence of multiple transcription factor-binding sites on the INGAP promoter (Taylor-Fishwick et al. 2003). Given the potential importance of INGAP expression with respect to the induction of islet neogenesis, delineation of the 
regulatory control of INGAP gene expression is an important pre-requisite for the development of strategies for the use of INGAP and related proteins as a novel therapy for diabetes.

\section{Acknowledgements}

We thank Despina Agapitos and Jieping Ding for excellent technical assistance and Sharon Clark for critical reading of the manuscript and valuable comments.

\section{Funding}

This study was supported in part by The Stem Cell Network of Canada, Genome Quebec, and Canadian Institutes for Health Research (CIHR). L R is a Chercheur National of the Fonds du Recherche Scientifique du Quebec. The authors declare that there is no conflict of interest that would prejudice the impartiality of this scientific work.

\section{References}

Abe K \& Watanabe S 1995 Apoptosis of mouse pancreatic acinar cells after duct ligation. Archives of Histology and Cytology 95 221-229.

Abe M, Nata K, Akiyama T, Shervani NJ, Kobayashi S, Tomioka-Kumagai T, Ito S, Takasawa S \& Okamoto H 2000 Identification of a novel Reg family gene, Reg III $\delta$, and mapping of all three types of Reg family gene in a 75-kilobase mouse genomic region. Gene 246 111-122.

Akiyama T, Takasawa S, Nata K, Kobayashi S, Abe M, Shervani NJ, Ikeda T, Nakagawa K, Unno M, Matsuno S et al. 2001 Activation of Reg gene, a gene for insulin-producing $\beta$-cell regeneration: poly (ADP-ribose) polymerase binds Reg promoter and regulates the transcription by autopoly (ADP-ribosyl)ation. PNAS 98 48-53.

Baggio LL \& Drucker DJ 2006 Therapeutic approaches to preserve islet mass in type 2 diabetes. Annual Reviews of Medicine 57 265-281.

Barcellos-Hoff MH, Aggeler J, Ram TG \& Bissell MJ 1989 Functional differentiation and alveolar morphogenesis of primary mammary cultures on reconstituted basement membrane. Development 105 223-235.

Bilder D 2004 Epithelial polarity and proliferation control: links from the Drosofila neoplastic tumor supressors. Genes and Development 18 1909-1925.

Birgersdotter A, Sandberg R \& Ernberg I 2005 Gene expression perturbation in vitro - a growing case for three-dimensional (3D) culture systems. Seminars in Cancer Biology 15 405-412.

Birkenkamp KU, Tuyt LM, Lummen C, Wierenga AT, Kruijer W \& Vellenga E 2000 The p38 MAP kinase inhibitor SB203580 enhances nuclear factor-kappa B transcriptional activity by a non-specific effect upon the ERK pathway. British Journal of Pharmacology 131 99-107.

Blaskovich MA, Sun J, Cantor A, Turkson J, Jove R \& Sebti SM 2003 Discovery of JSI-124 (cucurbitacin I), a selective Janus kinase/signal transducer and activator of transcription 3 signaling pathway inhibitor with potent antitumor activity against human and murine cancer cells in mice. Cancer Research 63 1270-1279.

Boerma D, Straatsburg IH, Offerhaus GJ, Gouma DJ \& van Gulik TM 2003 Experimental model of obstructive, chronic pancreatitis in pigs. Digestive Surgery 20 520-526.

Campbell IL, Hobbs MV, Dockter J, Oldstone MBA \& Allison J 1994 Islet inflammation and hyperplasia induced by the pancreatic islet-specific overexpression of interleukin-6 in transgenic mice. American Journal of Pathology 145 157-166.
Choi S-E, Choi K-M, Yoon I-H, Shin J-Y, Kim J-S, Park W-Y, Han D-J, Kim S-C, Ahn C, Kim JW et al. 2004 IL-6 protects pancreatic beta cells from pro-inflammatory cytokines-induced cell death and functional impairment in vitro and in vivo. Transplantation Immunology 13 43-53. Del Zotto H, Massa L, Rafaeloff R, Pittenger GL, Vinik A, Gold G, Reifel-Miller A \& Gagliardino JJ 2000 Possible relationship between changes in islet neogenesis and islet neogenesis-associated protein-positive cell mass induced by sucrose administration to normal hamsters. Journal of Endocrinology 165 725-733.

Del Zotto H, Borelli MI, Flores L, Garcia ME, Gomez Dumm CL, Chicco A, Lombardo YB \& Gagliardino JJ 2004 Islet neogenesis: an apparent key component of long-term pancreas adaptation to increased insulin demand. Journal of Endocrinology 183 321-330.

DiCosmo BF, Picarella D \& Flavell RA 1994 Local production of human IL-6 promotes insulitis but retards the onset of insulin-dependent diabetes mellitus in non-obese diabetic mice. International Immunology 6 1829-1837.

Dusetti N, Ortiz EM, Mallo GV, Dagorn J-C \& Iovanna JL 1995 Pancreatitisassociated protein (PAP I), an acute phase protein induced by cytokines. Journal of Biological Chemistry 270 22417-22421.

Dusetti NJ, Mallo GV, Ortiz EM, Keim V, Dagorn J-C \& Iovanna JL 1996 Induction of lithostathine/reg mRNA expression by serum from rats with acute pancreatitis and cytokines in pancreatic acinar AR-42J cells. Archives of Biochemistry and Biophysics 330 129-132.

Flores LE, Garcia ME, Borelli MI, Zotto HD, Alzugaray ME, Maiztegui B \& Gagliardino JJ 2003 Expression of islet neogenesis-associated protein in islets of normal hamsters. Journal of Endocrinology 177 243-248.

Gagliardino JJ, Zotto HD, Massa L, Flores LE \& Borelli MI 2003 Pancreatic duodenal homeobox-1 and islet neogenesis-associated protein: a possible combined marker of activateable pancreatic cell precursors. Journal of Endocrinology 17 249-259.

Guhaniyogi J \& Brewer G 2001 Regulation of mRNA stability in mammalian cells. Gene $26511-23$.

Gurr W, Yavari R, Wen L, Shaw M, Mora C, Christa L \& Sherwin RS 2002 A Reg family protein is overexpressed in islets from a patient with new-onset type I diabetes and acts as T-cell autoantigen in NOD mice. Diabetes 51 339-346.

Hamamoto N, Ashizawa N, Niigaki M, Kaji T, Katsube T, Endoh H, Watanabe M, Sumi S \& Kinoshita Y 2002 Morphological changes in the rat exocrine pancreas after pancreatic duct ligation. Histology and Histopathology 17 1033-1041.

Hay D 1993 Extracellular matrix alters epithelial differentiation. Current Opinion in Cell Biology 5 1029-1035.

Honda H, Nakamura H \& Otsuki M 2002 The elongated PAP II/Reg III mRNA is upregulated in rat pancreas during acute experimental pancreatitis. Pancreas 25 192-197.

Ishihara K \& Hirano T 2002 Molecular basis of the cell specificity of cytokine action. Biochimica et Biophysica Acta 1592 281-296.

Kakisis JD, Pradhan S, Cordova A, Liapis CD \& Sumpio BE 2005 The role of STAT-3 in the mediation of smooth muscle cell response to cyclic strain. International Journal of Biochemistry and Cell Biology 37 1396-1406.

Kim SK \& Hebrok M 2001 Intercellular signals regulating pancreas development and function. Genes and Development 15 111-127.

Kingsnorth A 1997 Role of cytokines and their inhibitors in acute pancreatitis. Gut 40 1-4.

Lipsett M, Aikin R, Castellarin M, Hanley S, Jamal AM, Laganiere S \& Rosenberg L 2006 Islet neogenesis: a potential therapeutic tool in type 1 diabetes. International Journal of Biochemistry and Cell Biology 38 498-503.

Liu M, Tanswell AK \& Post M 1999 Mechanical force-induced signal transduction in lung cells. American Journal of Physiology. Lung Cellular and Molecular Physiology 277 L667-L683.

Liu H, Radisky DC \& Bissell MJ 2005 Proliferation and polarity in breast cancer. Cell Cycle 4 646-649.

Livak KJ \& Schmittgen TD 2001 Analysis of relative gene expression data using real-time quantitative PCR and the $2^{-\Delta \Delta \mathrm{CT}}$ method. Methods 25 402-408.

Ma YL, Fujiyama C, Masaki Z \& Sugihara H 1997 Reconstruction of prostatic acinus-like structure from ventral and dorsolateral prostatic epithelial cells of the rat in three-dimensional collagen gel matrix culture. Journal of Urology 157 1025-1031. 
Means AL, Meszoely IM, Suzuki K, Miyamoto Y, Rustgi AK, Coffey RJ Jr, Wright CVE, Stoffers DA \& Leach SD 2005 Pancreatic epithelial plasticity mediated by acinar cell transdifferentiation and generation of nestin-positive intermediates. Development 132 3767-3776.

Nata K, Liu Y, Xu L, Ikeda T, Akiyama T, Noguchi N, Kawaguchi S, Yamauchi A, Takahashi I, Shervani NJ et al. 2004 Molecular cloning, expression and chromosomal localization of a novel human Reg family gene, Reg III. Gene 340 161-170.

Nefedova Y, Nagaraj S, Rosenbauer A, Muro-Cacho C, Sebti SM \& Gabrilovich DI 2005 Regulation of dendritic cell differentiation and antitumor immune response in cancer by pharmacologic-selective inhibition of the janus-activated kinase $2 /$ signal transducers and activators of transcription 3 pathway. Cancer Research 65 9525-9535.

Ogawa H, Fukushima K, Naito H, Funayama Y, Unno M, Takahashi K, Kitayama T, Matsuno S, Ohtani H, Takasawa S et al. 2003 Increased expression of HIP/PAP and regenerating gene III in human inflammatory bowel disease and a murine bacterial reconstitution model. Inflammatory Bowel Diseases 9 162-170.

Okamoto H 1999 The Reg gene family and Reg proteins: with special attention to the regeneration of pancreatic beta-cells. Journal of Hepatobiliary-Pancreatic Surgery 6 254-262.

Oue N, Mitani Y, Aung PP, Sakakura C, Takeshima Y, Kaneko M, Noguchi T, Nakayama H \& Yasui W 2005 Expression and localization of Reg IV in human neoplastic and non-neoplastic tissues: Reg IV expression is associated with intestinal and neuroendocrine differentiation in gastric adenocarcinoma. Journal of Pathology 207 185-198.

Pan J, Fukuda K, Saito M, Matsuzaki J, Kodama H, Sano M, Takahashi T, Kato T \& Ogawa S 1999 Mechanical stretch activates the JAK/STAT pathway in rat cardiomyocytes. Circulation Research 84 1127-1136.

Rafaeloff R, Pittenger GL, Barlow SW, Qin XF, Yan B, Rosenberg L, Duguid WP \& Vinik AI 1997 Cloning and sequencing of the pancreatic islet neogenesis associated protein (INGAP) gene and its expression in islet neogenesis in hamsters. Journal of Clinical Investigations 99 2100-2109.

Ratner RE, Feeley D, Buse JB \& Fisher JS 2005a Double-blind, placebocontrolled trial of Islet Neogenesis Gene Associated Protein (INGAP) therapy in type 2 diabetes (T2DM) subjects. American Diabetes Association, Annual Meeting, Proceedings, 12-LB (Abstract).

Ratner RE, Feeley D, Buse JB \& Schwartz SL $2005 b$ Double-blind, placebocontrolled trial of Islet Neogenesis Gene Associated Protein (INGAP) therapy in type 1 diabetes (T1DM) subjects. American Diabetes Association, Annual Meeting, Proceedings, 11-LB (Abstract).

Rood PP, Bottino R, Balamurugan AN, Fan Y, Cooper DK \& Trucco M 2006 Facilitating physiologic self-regeneration: a step beyond islet cell replacement. Pharmacological Research 23 227-242.

Rosenberg L 1998 Induction of islet cell neogenesis in the adult pancreas: the partial duct obstruction model. Microscopy Research and Technique $\mathbf{4 3}$ 337-346.

Rosenberg L, Duguid WP, Brown RA \& Vinik AI 1988 Induction of nesidioblastosis will reverse diabetes in Syrian golden hamster. Diabetes 37 334-341.

Rosenberg L, Vinik AI, Pittenger GL, Rafaeloff R \& Duguid WP 1996 Isletcell regeneration in the diabetic hamster pancreas with restoration of normoglycaemia can be induced by a local growth factor(s). Diabetologia 39 256-262.
Rosenberg L, Lipsett M, Yoon JW, Prentki M, Wang R, Jun HS, Pittenger GL, Taylor-Fishwick D \& Vinik AI 2004 A pentadecapeptide fragment of islet neogenesis-associated protein increases beta-cell mass and reverses diabetes in C57BL/6J mice. Annals of Surgery 240 875-884.

Ruff SJ, Chen K \& Cohen S 1997 Peroxovanadate induces tyrosine phosphorylation of multiple signaling proteins in mouse liver and kidney. Journal of Biological Chemistry 10 1263-1267.

Schmeichel KL \& Bissell MJ 2003 Modeling tissue-specific signaling and organ function in three dimensions. Journal of Cell Science 116 2377-2388.

Sumi S \& Tamura K 2000 Frontiers of pancreas regeneration. Journal of Hepatobiliary-Pancreatic Surgery 7 286-294.

Suzuki S, Miyasaka K, Jimi A \& Funakoshi A 2000 Induction of acute pancreatitis by cerulein in human IL-6 transgenic mice. Pancreas 21 86-92.

Takasawa S, Ikeda T, Akiyama T, Nata K, Nakagawa K, Shervani NJ, Noguchi N, Murakami-Kawaguchi S, Yamauchi A, Takahashi I et al. 2006 Cyclin D1 activation through ATF-2 in Reg-induced pancreatic beta-cell regeneration. FEBS Letters $\mathbf{5 8 0}$ 585-591.

Takatori A, Ohta E, Inenaga T, Horiuchi K, Ishii Y, Itagaki S, Kyuwa S \& Yoshikawa Y 2003 Protective effects of probucol treatment on pancreatic B-cell function of SZ-induced diabetic APA hamsters. Experimental Animals 52 317-327.

Taylor-Fishwick DA, Rittman S, Kendall H, Roy L, Shi W, Cao Y, Pittenger GL \& Vinik AI 2003 Cloning genomic INGAP: a Reg-related family member with distinct transcriptional regulation sites. Biochimica et Biophysica Acta 1638 83-89.

Thompson JE, Cubbon RM, Cummings RT, Wicker LS, Frankshun R, Cunningham BR, Cameron PM, Meinke PT, Liverton N, Weng Y et al. 2002 Photochemical preparation of a pyridone containing tetracycle: a Jak protein kinase inhibitor. Bioorganic and Medicinal Chemistry Letters 12 1219-1223.

Uwaifo GI \& Ratner RE 2005 Novel pharmacologic agents for type 2 diabetes. Endocrinology and Metabolism Clinics of North America 34 155-197.

Yamada KM, Pankov R \& Cukierman E 2003 Dimensions and dynamics in integrin function. Brazilian Journal of Medical and Biological Research 36 959-966.

Yuan S, Duguid WP, Agapitos D, Wyllie B \& Rosenberg L 1997 Phenotypic modulation of hamster acinar cells by culture in collagen matrix. Experimental Cell Research 237 247-258.

Zauberman A, Zipori D, Krupsky M \& Ben-Levy R 1999 Stress activated protein kinase p38 is involved in IL-6 induced transcriptional activation of STAT3. Oncogene 18 3886-3893.

Zhang YW, Ding LS \& Lai MD 2003 Reg gene family and human diseases. World Journal of Gastroenterology 9 2635-2641.

Received 9 February 2006

Received in final form 26 June 2006

Accepted 27 June 2006

Made available online as an Accepted Preprint

17 July 2006 